\title{
O USO DE COBRE E ANTIBIÓTICO COMO PROMOTORES DE CRESCIMENTO EM RAÇÕES PARA FRANGOS DE CORTE
}

\author{
MÁRCIA CHRISTINA IAFIGLIOLA \\ Zootecnista
}

Orientador: Prof. Dr. JOSÉ FERNANDO MACHADO MENTEN

Dissertação apresentada à Escola Superior de Agricultura "Luiz de Queiroz", Universidade de São Paulo, para obtenção do título de Mestre em Agronomia, Área de Concentração: Ciência Animal e Pastagens

\author{
PIRACICABA \\ Estado de São Paulo - Brasil
}

Fevereiro - 2000 


\section{Dados Internacionais de Catalogação na Publicação (CIP) DIVISĀO DE BIBLIOTECA E DOCUMENTAÇĀO - Campus "Luiz de Queiroz"/USP}

lafigliola, Márcia Christina

O uso de cobre e antibiótico como promotores de crescimento em raçōes para frangos de corte / Márcia Christina lafigliola. - - Piracicaba, 2000.

78 p. : il.

Dissertação (mestrado) - - Escola Superior de Agricultura Luiz de Queiroz, 2000. Bibliografia.

1. Antibiótico 2. Cama de galinheiro 3. Cobre 4. Crescimento animal 5. Díeta animal 6. Frango de corte 7. Ração 8 . Resíduo animal 9. Temperatura animal I. Título

CDD 636.513

Germitida a copia total ou parcial deste documento, desde que citadaa fonte - 0 autor: 


\section{Dedico}

Aos meus amados pais, Michele e Sonia por terem me apoiado em todos os momentos da minha vida

\section{Ofereço}

Ao meu irmão Inácio e a minha sobrinha Thaís pelo amor e alegria sempre presentes 


\section{AGRADECIMENTOS}

\section{À DEUS.}

Ao Prof. Dr. José Fernando Machado Menten, exemplo de dedicação e competência, agradeço a oportunidade, orientação e amizade.

À Fundação Coordenação de Aperfeiçoamento de Pessoal de Nivel Superior (CAPES) pela bolsa de estudos concedida.

A todos os professores do Departamento de Produção Animal, em especial ao Prof. Dr. Valdomiro S. Miyada pelos valiosos ensinamentos.

À Profa Maria Cristina Stolf Nogueira pela orientação nas análises estatísticas.

Às secretárias do Departamento de Produção Animal, Cláudia C. de Camargo e Vera Lúcia Graciano que sempre me atenderam com muita atenção e carinho.

Aos funcionários do Departamento de Produção Animal, especialmente ao Chico, Antônio Carlos e Sr. Bonato pela colaboração durante toda a fase experimental.

À bibliotecária Eliana $M$. Garcia pela revisão das referências bibliográficas e a todos os funcionários da Biblioteca Central pelo pronto atendimento.

Aos amigos do curso de Pós-Graduação Aline Calil Racanicci e Juliano Gaiotto pelo convívio e incentivo durante o curso de mestrado, bem como auxílio na condução e coleta dos dados experimentais.

Ao estagiário do Departamento de Produção Animal - Setor Avicultura Marcos Urso pelo auxílio na coleta dos dados experimentais.

À amiga da Pós-Graduação Adriana Ayres Pedroso pelas sugestões e a ajuda prestada na fase final do trabalho. 
Às minhas grandes amigas Adriana Pontes e Alexsandra Caseiro pelos anos de amizade e companheirismo.

À família Gobeth, em especiai ao Julian peio apoio e amizade.

À SUPREMAIS Produtos Bioquímicos Ltda. pelas análises laboratoriais.

À Griftin Corporation pela doação do citrato de cobre.

À PFISER Ltda. pela doação do antibiótico Virginiamicina.

A todos aqueles que de alguma forma auxiliaram na realização deste trabalho. 


\section{SUMÁRIO}

Página

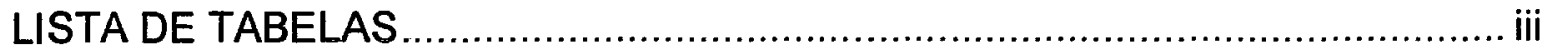

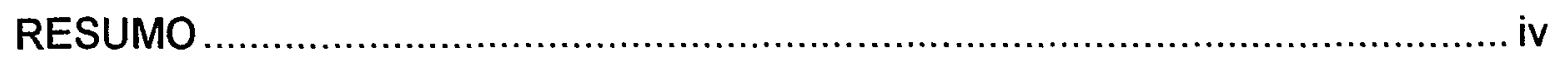

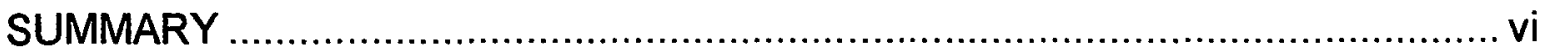

1 INTRODUÇÃO

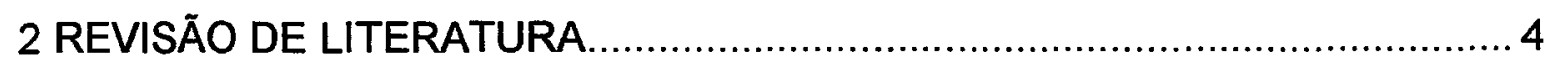

2.1 Agentes antimicrobianos como promotores de crescimento........................ 4

2.2 Modo de ação dos promotores de crescimento ........................................... 5

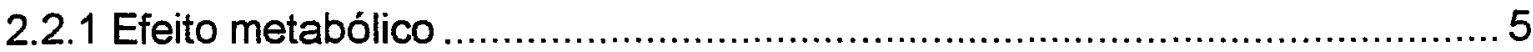

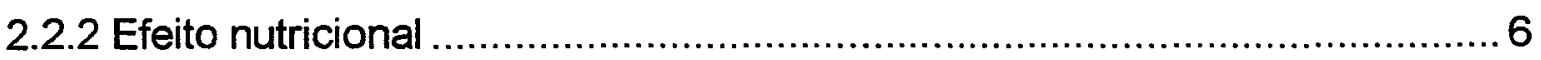

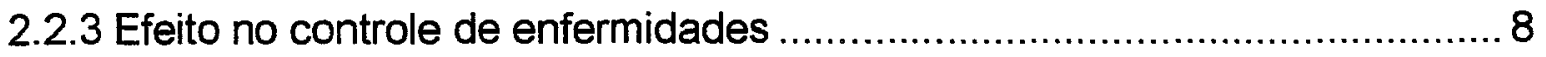

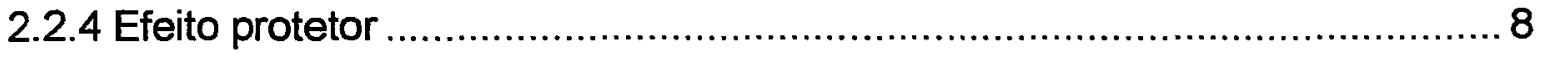

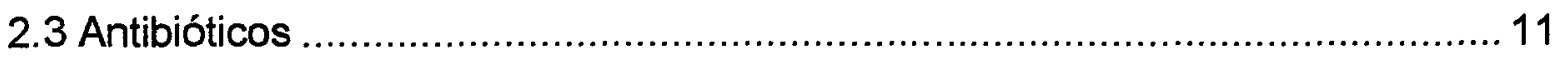

2.3.1 O uso de antibióticos como promotores de crescimento .......................... 11

2.3.2 Situação atual sobre o uso de antibióticos como promotores de

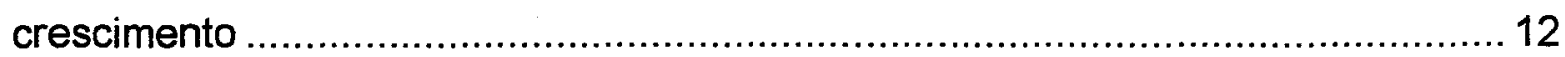

2.3.3 Resistência bacteriana aos antibióticos ................................................... 13

2.3.4 Composição da população microbiana intestinal de uma ave saudável...... 17

2.3.5 Antibióticos e a sua importância na ativação do sistema imune .................. 19

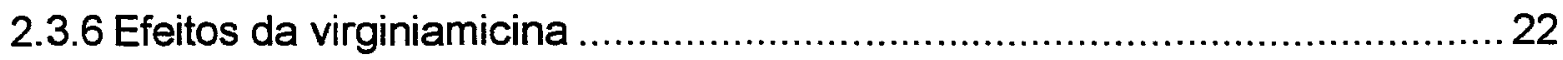

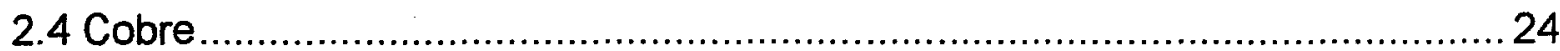

2.4.1 Importância, exigência nutricional e toxicidade do cobre...........................2 24

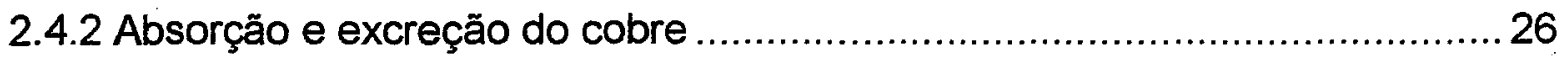

2.4.3 Efeito de altas doses de cobre e suas fontes ......................................... 27

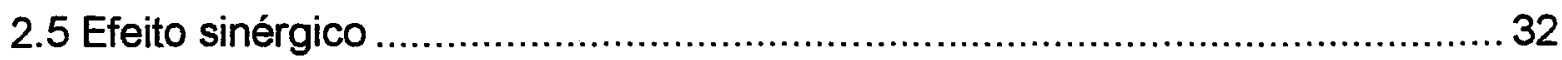




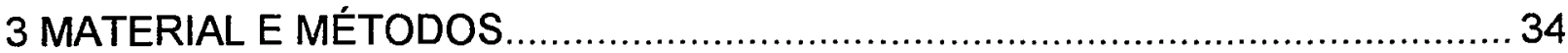

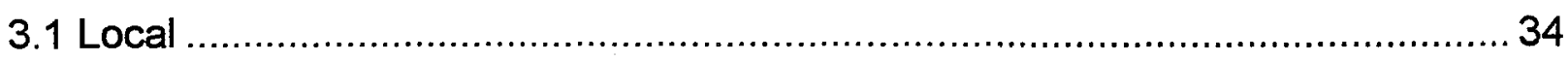

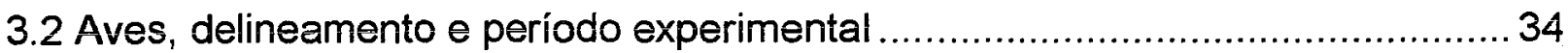

3.3 Instalações, preparação e condução do experimento ........................................ 35

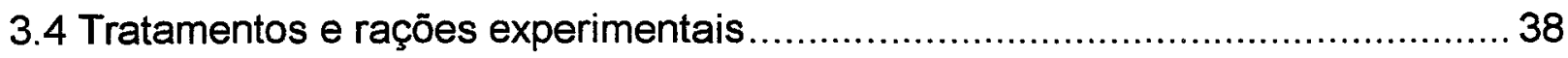

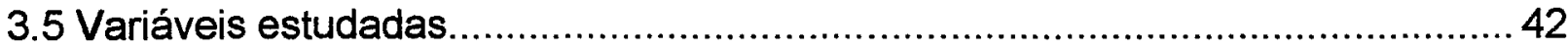

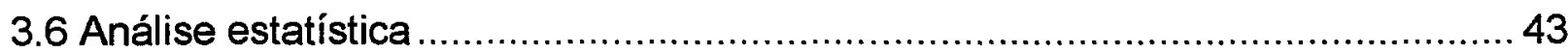

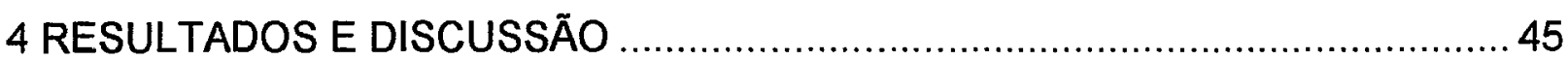

4.1 Desempenho dos frangos de corte 1 a 21 dias de idade ................................. 45

4.2 Desempenho dos frangos de corte 22 a 42 dias de idade ............................... 48

4.3 Desempenho dos frangos de corte 1 a 42 dias de idade ................................ 49

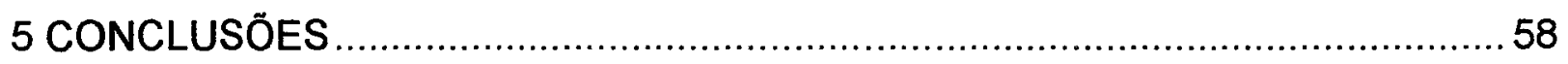

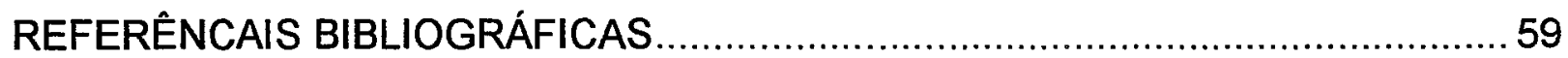

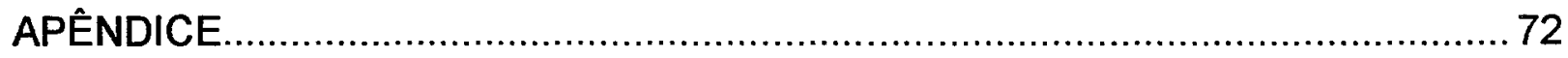




\section{LISTA DE TABELAS}

1 Distribuição de bactérias intestinais em frangos de corte

2 Composição percentual e valores calculados das rações basais ..... 40

3 Esquema da Análise de Variância

4 Peso vivo (PV), ganho de peso (GP), consumo de ração (CR), conversão alimentar (CA) e mortalidade + refugagem (MR) dos frangos de corte alimentados com rações contendo diferentes microingredientes de alimentação, na fase inicial ( 1 a 21 dias).

5 Ganho de peso (GP), consumo de ração (CR), conversão alimentar (CA) e mortalidade + refugagem (MR) dos frangos de corte alimentados com rações contendo diferentes micOroingredientes de alimentação, na fase final (22 a 42 dias)

6 Peso vivo (PV), ganho de peso (GP), consumo de ração (CR) conversão alimentar (CA) e mortalidade + refugagem (MR) dos frangos de corte alimentados com rações contendo diferentes microingredientes de alimentação, no período total de criação das aves ( 1 a 42 dias)

7 Análise microbiológica da cama do galpão experimental

8 Temperatura retal média dos frangos de corte alimentados com rações contendo diferentes microingredientes de alimentação. Período experimental de 7 a 42 dias 


\title{
O USO DE COBRE E ANTIBIÓTICO COMO PROMOTORES DE CRESCIMENTO EM RAÇÕES PARA FRANGOS DE CORTE
}

\author{
Autora: MÁRCIA CHRISTINA IAFIGLIOLA \\ Orientador: Prof. Dr. JOSÉ FERNANDO MACHADO MENTEN
}

\section{RESUMO}

Este estudo teve como objetivo avaliar o efeito da suplementação de citrato cúprico como uma fonte não convencional de cobre $(\mathrm{Cu})$, do antibiótico comercial virginiamicina e o efeito sinérgico entre o citrato cúprico e o antibiótico, além do sulfato de cobre, como promotores de crescimento sobre o desempenho e temperatura retal de frangos de corte.

O experimento foi conduzido no aviário experimental do Departamento de Produção Animal da ESALQ/USP, Piracicaba/SP. Utilizou-se o delineamento em blocos casualizados com cinco tratamentos e seis repetições com 40 aves por unidade experimental. As aves foram criadas em camas reutilizadas com 0 intuito de aumentar 0 desafio microbiano, simulando condições de campo.

Durante o período experimental de 42 dias, as aves receberam ração baseada em milho e farelo de soja não suplementada (CONTROLE), ou essa ração adicionada de $200 \mathrm{mg} \mathrm{Cu} / \mathrm{kg}$ na forma de sulfato cúprico (SULFATO), ou $75 \mathrm{mg} \mathrm{Cu} / \mathrm{kg}$ na forma de citrato cúprico (CITRATO), ou $20 \mathrm{mg}$ virginiamicina/kg (VM), ou $75 \mathrm{mg} \mathrm{Cu} / \mathrm{kg}$ (citrato cúprico)+ $20 \mathrm{mg}$ virginiamicina/kg (CITRATO + VM). 
A ração farelada e a água foram fornecidas à vontade. As pesagens, medições da temperatura retal, cálculos do ganho de peso (GP), consumo de ração (CR) e a conversão alimentar (CA) das aves foram feitos semanalmente. Para fins estatísticos o período experimental foi agrupado em três fases (1-21; 22-42 e 1-42 dias de idade). As variáveis dependentes GP, $\mathrm{CR}, \mathrm{CA}$, peso vivo (PV), mortalidade + refugagem (MR) e temperatura retal (TR) foram submetidas à análise de variância pelo procedimento GLM (SAS).

Não se observou efeito $(P>0,05)$ dos promotores de crescimento em nenhuma variável estudada na fase inicial (1-21 dias). No período de 22 a 42 dias a VM proporcionou melhora $(P<0,05)$ na $C A$, da ordem de $2,7 \%$ quando comparada ao CONTROLE, porém não diferiu dos demais tratamentos $(P>0,05)$; os tratamentos também não afetaram GP nem $C R(P>0,05)$. SULFATO resultou em maior MR $(5 \%)(P<0,05)$ das aves quando comparado com o CITRATO, VM e CITRATO + VM (0,83; 1,25 e 1,25\%, respectivamente), porém não diferiu significativamente do CONTROLE. Considerando o período total (1-42 dias) não verificou qualquer efeito dos promotores de crescimento sobre PV, GP, CR ou CA; as aves que receberam os tratamentos SULFATO e CONTROLE apresentaram maiores MR $(P<0,05) \quad(6,25$ e $3,75 \%$, respectivamente) em comparação ao CITRATO, VM e CITRATO + VM (1,25; 2,08 e $1,67 \%$, respectivamente). Não foi verificado efeito sinérgico para qualquer das variáveis estudadas quando se usou CITRATO + VM. A TR apresentou diferença significativa $(P<0,05)$ na quarta semana, sendo que o CITRATO + VM propiciou diminuição de $0,29^{\circ} \mathrm{C}$ quando comparado ao CONTROLE e VM, porém não diferiu dos demais tratamentos.

$O$ pequeno efeito dos promotores de crescimento observado neste estudo pode ser atribuído ao excelente desempenho das aves que receberam a dieta não suplementada. Aparentemente não se conseguiu aumentar o desafio microbiano através do uso de cama reutilizada. 


\title{
COPPER AND ANTIBIOTIC AS GROWTH PROMOTERS IN RATIONS FOR BROILER CHICKENS
}

\author{
Author: MÁRCIA CHRISTINA IAFIGLIOLA \\ Adviser: Prof. Dr. JOSÉ FERNANDO MACHADO MENTEN
}

\section{SUMMARY}

The objective of this study was to evaluate the effects of supplementing cupric citrate, as a non-conventional source of copper $(\mathrm{Cu})$, the commercial antibiotic virginiamycin and both combined, and copper sulfate in the diet of broiler chickens on performance and rectal temperature.

The chicks were raised on reutilized litter in order to increase the microbism, simulating field conditions. The experimental design was randomized blocks with five treatments and six replicates and 40 birds per pen. The treatments consisted of a basal corn-soybean meal diet (CONTROL) or this diet supplemented with $200 \mathrm{mg}$ Cu/ $\mathrm{kg}$ as copper sulfate (SULFATE), or 75 $\mathrm{mg} \mathrm{Cu} / \mathrm{kg}$ as copper citrate (CITRATE), or $20 \mathrm{mg}$ virginiamycin $/ \mathrm{kg}$ (VM), or CITRATE + VM.

Mesh feed and water were supplied ad libitum for 42 days. Weekly the birds were weighed and the rectal temperatures were taken; weight gain, feed intake and feed conversion were calculated. The results relative to the 1-21 d, 22-42 d and 1-42 d were analysed, in addition to mortality and rectal temperatures. 
In the 1-21 d period treatments did not affect any variable $(P>05)$. VM improved feed conversion compared to CONTROL $(P<.05)$ in $2,7 \%$, but not to the other treatments in the 22-42 d. SULFATE resulted in higher mortality compared to CITRATE, VM and CITRATE + VM (5\% vs .83, 1.25 and 1.25 , respectively, $\mathrm{P}<.05$ ) but did not differ from CONTROL. In the $1-42 \mathrm{~d}$ period the additives had no effects on liveweight, weight gain, feed intake and feed conversion. The mortality of broilers receiving CONTROL and SULFATE diets was higher than those fed the other diets $(P<.05)$. Synergistic effect was not observed in any variable when CITRATE + VM was fed. Rectal temperature was $.29{ }^{\circ} \mathrm{C}$ lower for CITRATE + VM birds compared to CONTROL and VM $(P<.05)$.

The small effect of the growth promoters observed in this study may be due to the excellent performance of the broilers receiving the unsupplemented diet. Apparently an increase in the microbial challenge through the use of reutilized litter was not achieved. 


\section{INTRODUÇÃO}

A avicultura brasileira ocupa papel de destaque mundial, com uma produção anual de 4,3 milhões de toneladas de carne de frango e 1,23 bilhões de dúzias de ovos. Com o crescente avanço no processo produtivo está sendo possivel uma diminuição do custo de produção, revertendo os benefícios principalmente para as classes menos favorecidas, podendo assim consumir proteina de ótima qualidade por um preço mais acessivel. $O$ consumo per capita de carne de frango no Brasil em 1999 foi $26 \mathrm{~kg}$. Esse grande desenvolvimento deve-se aos avanços do melhoramento genético, nutrição, manejo e sanidade.

Em avicultura, a alimentação é um dos fatores mais importantes e decisivos, já que as rações representam cerca de $70 \%$ do custo total de produção. $O$ uso de agentes antimicrobianos como promotores de crescimento em rações para frangos de corte prestam uma contribuição significativa na redução dos custos de produção. Estes promotores de crescimento adicionados às rações tem a finalidade de prevenir ou controlar doenças, estimular o crescimento e melhorar a conversão alimentar.

Os antibióticos são agentes antimicrobianos sintetizados por microrganismos vivos como leveduras, fungos e bactérias, podem ser usados em rações animais em niveis subterapêuticos (dosagem menor do que a recomendada para ação medicamentosa), favorecendo uma ação promotora do crescimento. Um outro agente antimicrobiano muito utilizado que também exibe caracteristica de promover o crescimento é o cobre, um micromineral essencial com ação promotora do crescimento quando usado 
em níveis acima do exigido nutricionalmente. Existem várias fontes de cobre, umas com maior disponibilidade do mineral e outras com menor; o sulfato de cobre pentahidratado, atualmente é o mais usado. Recentemente foram feitas algumas pesquisas estudando o citrato de cobre como uma boa alternativa, porém os dados da literatura não são completamente concordantes.

A indústria animal tem passado por mudanças significativas nos últimos anos, não somente no âmbito nacional como mundial. Existe uma grande pressão quanto à segurança do uso dos promotores de crescimento em relação à saúde humana. Pode-se citar como principais preocupações a possibilidade de indução de resistência cruzada de bactérias patogênicas ao homem, presença de resíduos na carne, ovos ou leite e agressão ao meio ambiente devido a grande quantidade de resíduos de cobre eliminados pelos animais poluindo o solo e a água.

Entretanto não há comprovação científica de que os antibióticos promotores de crescimento utilizados nas rações de aves, suinos e bovinos deixem resíduos nos alimentos que possam provocar impactos negativos à saúde do homem.

Em relação ao cobre, provavelmente é possivel diminuir seu resíduo no ambiente com fontes mais disponiveis, como por exemplo o citrato de cobre; esta se trata de uma fonte orgânica que tem demonstrado ser tão eficiente em promover o crescimento animal quanto o sulfato de cobre com a vantagem de ser utilizado em menores concentrações.

A avicultura moderna tem se caracterizado pela alta densidade de criação expondo a ave a um contato maior aos antígenos, aumentando o desafio microbiano. Os promotores de crescimento citados acima possuem propriedades antimicrobianas podendo reduzir a microflora intestinal patogênica da ave, com isso submetendo-a a menor estresse imunológico. 0 estresse imunológico desencadeia reações que envolvem respostas imunes, 
ocorrendo aumento na temperatura corporal e na taxa metabólica, bem como anorexia e consequentemente perda de peso e crescimento retardado.

Este estudo teve como objetivo avaliar a eficácia da suplementação de alto nível de cobre, através da fonte citrato de cobre e do antibiótico virginiamicina, nas dietas de frangos de corte como promotores de crescimento e o efeito sinérgico entre o cobre e o antibiótico. Além disso, a ativação do sistema imune das aves foi estudado de forma indireta através da medição da temperatura corporal. 


\section{REVISÃO DE LITERATURA}

\subsection{AGENTES ANTIMICROBIANOS COMO PROMOTORES DE CRESCIMENTO}

O uso de agentes antimicrobianos como aditivos às rações para prevenir ou controlar doenças, estimular o crescimento e melhorar a conversão alimentar tem sido prática comum na avicultura industrial há quase 50 anos.

A legislação que regulamenta a inspeção e a fiscalização dos produtos destinados à alimentação animal (Decreto $\mathrm{n}^{0} \mathbf{7 6 . 9 8 6}$, de 06 de janeiro de 1976) define em seu artigo $4^{0}$, item VII, que aditivo é "toda substância intencionalmente adicionada ao alimento, com a finalidade de conservar, intensificar ou modificar suas propriedades, desde que não prejudique seu valor nutritivo, como os antibióticos, corantes, conservantes, antioxidantes e outros" (Compêndio, 1998).

Foi lançado em 1998 o Compêndio Brasileiro de Alimentação Animal que entre outras informações, procurou padronizar a terminologia usada pela indústria, técnicos e demais profissionais da área.

O termo aditivo tem várias definições e muitas vezes dão conotações não saudáveis do ponto de vista do consumidor, além de significados equivocados. Com a necessidade de minimizar esses problemas o referido Compêndio trata os "aditivos" como microingredientes de alimentação (Butolo, 1998).

Os microingredientes de alimentação são classificados segundo o Compêndio Brasileiro de Alimentação Animal em 13 grupos com definições claras quanto a sua natureza e função científica na nutrição; entre eles temos: acidificantes, antioxidantes, corantes, promotores de crescimento e outros, 
divididos em 3 classes com seu modo de ação específico ou características funcionais: pró-nutriente, coadjuvantes de elaboração e profiláticos.

Os microingredientes de alimentação utilizados em rações animais variam quanto aos objetivos de seu emprego; entre os mais utilizados estão os promotores de crescimento e/ou eficiência alimentar; os agentes antimicrobianos fazem parte deste grupo.

Os agentes antimicrobianos, segundo Cromwell (1991), incluem os antibióticos (substâncias de ocorrência natural produzidas por fungos, leveduras e outros microorganismos), os quimioterápicos (sintetizados quimicamente) e o elemento mineral cobre ( $\mathrm{Cu}$ ) quando presente em altas concentrações na dieta.

\subsection{MODO DE AÇÃO DOS PROMOTORES DE CRESCIMENTO}

$O$ modo de ação pelo qual os promotores de crescimento agem vem sendo estudado desde a década de 50 , tendo sido propostos inúmeros mecanismos para explicar o efeito promotor do crescimento dessas substâncias; contudo, o modo de ação ainda não está totalmente elucidado. Baseando-se em dados sumarizados por vários autores, pode-se dizer que os promotores de crescimento exercem os seguintes efeitos sobre o crescimento e produção: 1) efeito metabólico; 2) efeito nutricional; 3) efeito no controle de enfermidades; 4) efeito protetor (Hays, 1969; Visek, 1978; Crowmell, 1991).

\subsubsection{Efeito Metabólico}

Através desse mecanismo os promotores de crescimento, de alguma forma, afetam diretamente a taxa ou o padrão de processos metabólicos do animal. O efeito metabólico não explica o modo de ação dos promotores de crescimento não absorvidos pelo trato gastrointestinal (Crowmell, 1991).

Zhou et al. (1994a) constataram que a suplementação com altos niveis de cobre em dietas iniciais de leitões aumentou os níveis de mRNA para hormônio do crescimento, independente do método de alimentação (restrição alimentar ou ad libitum). Os autores sugeriram que o maior efeito do cobre no desempenho 
animal está provavelmente relacionado com o estímulo do consumo alimentar e este por sua vez promove o crescimento.

Zhou et al. (1994b), na tentativa de elucidar o modo de ação do cobre como promotor do crescimento, propuseram a ação sistêmica deste elemento. Nesse estudo os suínos receberam injeção intravenosa de cobre-histidinato (Cuhis). Avaliaram os niveis de mRNA para hormônio do crescimento e observaram um forte aumento em resposta a doses crescentes de Cu-his, entretanto sem efeito significativo. Outro achado bastante interessante foi em relação a atividade da superóxido desmutase (cuproenzima, responsável pela eliminação de radicais livres). Os autores verificaram um aumento linear $(P<0,05)$ na atividade da enzima com niveis crescentes de Cu-his. Em relação ao desempenho foi verificado uma resposta quadrática na variável ganho de peso para os niveis estudados.

Bakalli et al. (1995), levantando a hipótese que a suplementação com altos niveis de cobre poderia reduzir o conteúdo de colesterol no plasma e nos músculos do peito de frangos de corte, conduziram três experimentos suplementando dietas basais com $250 \mathrm{mg}$ de cobre/ $\mathrm{kg}$ de ração na forma de sulfato de cobre por diferentes periodos de criação. Os dados experimentais confirmaram uma diminuição no colesterol plasmático e muscular, e também um aumento no ganho de peso de frangos de corte quando receberam altos níveis de cobre em comparação com aqueles que não o receberam. Além disso, foi observado que $250 \mathrm{ppm}$ de cobre reduziu a sintese de glutationa e talvez seja esse o mecanismo pelo qual o cobre auxilia na redução do colesterol orgânico, pois a glutationa é conhecida por regular a biossíntese de colesterol através do estímulo da enzima 3-hidroxi-3-metilglutaril coenzima A (HMG-CoA) redutase.

\subsubsection{Efeito Nutricional}

Um segundo modo de ação intitulado como efeito nutricional propõe que os promotores de crescimento podem reduzir as necessidades de certos nutrientes das seguintes formas: (1) estimulando o crescimento de certos microrganismos que sintetizam vitaminas ou aminoácidos; (2) aumentando a 
disponibilidade de nutriente através da formação de quelatos; (3) diminuindo os organismos que competem com o animal por nutrientes.

Monson et al. (1954) relataram um aumento na síntese de ácido fólico produzido por coliformes intestinais dos frangos de corte, com o uso de bacitracina-penicilina e aureomicina. $O$ crescimento dos frangos de corte alimentados com dietas contendo quantidades limitantes de ácido fólico foi estimulado pela suplementação com os antibióticos quando essas aves foram comparadas com aves alimentadas com dietas não suplementadas. Com base nesses resultados, os autores concluíram que essa economia de vitaminas proporcionada pelos antibióticos pode ser uma possível explicação pelo qual esses agentes antimicrobianos estimulam o crescimento animal.

Entretanto, atualmente as dietas são balanceadas, suplementadas com vitaminas e minerais e talvez o efeito nutricional proporcionado pelos agentes antimicrobianos tenha pouca ou nenhuma influência sobre o desempenho animal. Maynard et al. (1984) comentaram que as diferenças no desempenho de animais controle e os tratados com antibióticos se tornam mais evidentes com o uso de dietas marginais ou ligeiramente deficientes em proteínas, vitaminas ou em certos elementos químicos.

A utilização do fósforo foi melhorada com a adição de virginiamicina nas dietas de frangos de corte. Foi encontrado melhora na eficiência alimentar e redução na quantidade de fósforo consumido por grama de peso vivo. A adição de virginiamicina na dieta proporcionou aumento $(P<0,05)$ no peso vivo das aves quando comparadas às não suplementadas (Buresh et al., 1985).

A digestibilidade da gordura foi melhorada com a suplementação de 250 ppm de cobre em rações para leitões desmamados. Em adição, a dieta com alto nivel de cobre $(250 \mathrm{ppm})$ incrementou a retenção de $N(P<0,05)$ e energia $(P<0,09)$ em contraste ao tratamento com baixo nível (15 ppm). Além disso, houve interação significativa entre níveis de $\mathrm{Cu}$ e gordura, sendo que a dieta com 250 ppm de $\mathrm{Cu}$ e $5 \%$ de gordura promoveu aumento na retenção de alguns microminerais ( $\mathrm{Cu}, \mathrm{Fe}$ e $\mathrm{Mn})$; consequentemente proporcionou melhora no 
ganho de peso $(P<0,01)$ e conversão alimentar $(P<0,01)$ quando comparada com as demais dietas (Dove, 1995).

\subsubsection{Efeito no Controle de Enfermidades}

Um outro mecanismo é através da eliminação dos microorganismos causadores de manifestações clínicas ou subclínicas de doenças, que provocam o declínio no ritmo de crescimento.

Stutz \& Lawton (1984) avaliaram o efeito de diversos agentes antimicrobianos (bacitracina, penicilina, clortetraciclina, oxitetraciclina, entromicina, tilosina, virginiamicina, lincomicina, bambermicina e carbadox) sobre o desempenho, peso ileal e o número de Clostridium perfringens no íleo de frangos de corte alimentados com dietas à base de milho e farelo de soja. A suplementação com $55 \mathrm{ppm}$ dos antibióticos citados acima proporcionou melhora no ganho de peso e conversão alimentar e reduzindo significativamente o peso do íleo e o número de $C$. perfringens no íleo das aves alimentadas com antibióticos quando comparadas com 0 controle. Os resultados deste experimento suportam o conceito que os antimicrobianos são permissores do crescimento e evidenciam que o $C$. perfringens é uma bactéria depressora do crescimento.

\subsubsection{Efeito Protetor}

Através do qual os promotores de crescimento podem inibir o crescimento de organismos produtores de toxinas. Visek (1978) propôs que a produção de amônia proveniente da uréia pela ação da microflora intestinal é responsável pela depressão no crescimento em animais convencionais.

Yen \& Nienaber (1993) verificaram que a alimentação com 250 ppm de cobre reduziu a quantidade total de amônia absorvida via veia portal de suínos durante as primeiras 6 horas do periodo pós-prandial. Efeito similar foi observado em suínos alimentados com 55 ppm de carbadox (Yen \& Pond, 1990).

O cobre, assim como o antibiótico, possui propriedades antimicrobianas e por este motivo acredita-se, então, que modo de ação desses compostos seja 
semelhante (Cromwell, 1991). Várias linhas de pesquisas sustentam a hipótese que esses promotores de crescimento estimulam a melhora no crescimento devido a ação na microflora intestinal. Isto é suportado pelo resultado de estudos comparando respostas no crescimento de frangos convencionais e germ-free, isto é animais isentos de germes. As aves germ-free crescem mais rápido e com uma maior eficiência quando comparadas às aves convencionais, além de não responderem aos antibióticos promotores de crescimento. Em adição, frangos convencionais alimentados com antibióticos têm crescimento e eficiência alimentar próximos daqueles encontrados em frangos germ-free (Feighner \& Dashkevicz, 1987).

A maioria dos processos de digestão e absorção ocorre no intestino delgado; a quebra dos alimentos se faz no lúmen do intestino sob influência das enzimas digestivas. Contudo, parte da digestão ocorre na superfície das células da mucosa (enterócitos), pela ação das enzimas de membrana ou mesmo dentro delas. Os enterócitos são originários, por processo mitótico, nas criptas intestinais, células estas que adquirem a habilidade de digerir e absorver nutrientes durante a migração para a extremidade da vilosidade (Macari et al., 1994).

É de suma importância manter a integridade do trato gastrointestinal, pois quando este é submetido a injúrias físicas, químicas e biológicas, o organismo das aves responde rapidamente com um processo de descamação e reação inflamatória do tecido conjuntivo; podendo ocorrer também um aumento no peso do trato gastrointestinal principalmente pelo aumento da lâmina própria (Benício, 1996). Esses eventos influenciam os processos de digestão e absorção dos nutrientes prejudicando o desenvolvimento e produção animal.

Reduções no peso do intestino delgado foram observadas em frangos de corte alimentados com virginiamicina, considerando ser este um dos prováveis mecanismos pelos quais a absorção de nutrientes é melhorada pelo uso de antibióticos (Henry et al., 1987; lzart et al., 1989). 
Cook \& Bird (1973) demonstraram que aves convencionais apresentaram área de vilosidade, lâmina própria e profundidade de cripta maiores $(P<0,01 ; P$ $<0,05 ; P<0,05$, respectivamente) quando comparadas com aves germ-free.

Em uma pesquisa realizada por Krinke \& Janrroz (1996), foi observado que a adição de avorpacina em dietas para frangos de corte proporcionou resposta positiva no ganho de peso em relação ao controle. Foi verificado diminuição na atividade mitótica das células do intestino delgado (duodeno) e dos hepatócitos nas aves tratadas quando comparada com as não tratadas, sugerindo que aves que receberam o antibiótico se assemelham aos animais germ-free que possuem um turnover celular menor que dos animais convencionais, devido ao número reduzido de bactérias produtoras de toxinas.

O aumento na taxa de turnover celular resulta na eliminação muito rápida dos enterócitos, portanto as células jovens não expressam sua capacidade máxima para secretar enzimas, digerir ou absorver nutrientes. A menor quantidade de nutrientes absorvidos pelo animal resulta em maior disponibilidade de nutrientes para as bactérias e consequentemente há maior produção de toxina bacteriana. Essa toxina muitas vezes é absorvida e biotransformada pelo fígado resultando num aumento do órgão, dos hepatócitos e do turnover celular hepático (Benício, 1996).

Podemos confirmar este fato com os dados apresentados por Krinke \& Janrroz (1996); os autores observaram a hipertrofia dos hepatócitos nos animais controle em comparação com aves suplementadas com antibióticos.

Feighner \& Dashkevicz (1987) estudaram o efeito de diversos antibióticos no desempenho de frangos de corte e na atividade da enzima bacteriana coliltaurina hidrolase. Esta enzima é responsável pela desconjugação e dehidroxilação dos sais biliares, estando envolvida no metabolismo de lipídeos influenciando o ganho de peso (GP) e conversão alimentar (CA) de frangos de corte. Os dados desta pesquisa demonstraram que a suplementação com antibióticos promoveu uma melhora média de $24,8 \%$ no GP e $12,51 \%$ na CA de frangos de corte quando comparadas com o controle. Em relação à enzima 
bacteriana, foi possivel verificar uma queda acentuada na sua atividade em frangos tratados com antibiótico quando comparados àqueles que não foram suplementados. Os pesquisadores sugeriram que esses microingredientes de alimentação são capazes de melhorar o desempenho animal em função da diminuição no número de bactérias intestinais que hidrolisam os sais biliares prejudicando a digestão e absorção das gorduras.

Deve-se atentar ao fato que a aceitação de um determinado mecanismo não exclui a atuação de outro(s) e que é provável que mais de um mecanismo atue simultaneamente para proporcionar a resposta obtida com os promotores de crescimento.

\subsection{ANTIBIÓtICOS}

\subsubsection{O uso de antibióticos como promotores de crescimento}

Os antibióticos são compostos sintetizados por organismos vivos que inibem o crescimento de outros. Quando usados em niveis subterapêuticos em rações de animais proporcionam aumento no ganho de peso, melhora na conversão alimentar e redução na mortalidade. Desta forma são classificados como microingrediente alimentar, pertencendo a classe dos pró-nutrientes e do grupo dos promotores de crescimento.

A descoberta da ação estimuladora dos antibióticos sobre o crescimento foi feita quase que por acaso, por um grupo de pesquisadores americanos no final dos anos 40. Stokstad ${ }^{1}$ et al., citados por Crowmell (1991), realizando ensaios com vitamina $B_{12}$, suplementaram rações para frangos de corte com fontes não refinadas dessa vitamina, obtida como subproduto da fermentação do microorganismo Streptomyces aureofaciens e observaram um aumento na taxa de crescimento que excedia a esperada pela quantidade de vitamina usada. Investigações posteriores esclareceram que a ação promotora do crescimento foi devido à presença do antibiótico clortetraciclina no resíduo.

Stokstad, E. L. R. et al., 1949 Journal Biol. Chem. 180:6471 
Desde então muitas pesquisas vem sendo realizadas a fim de estudar o efeito de antibióticos como promotores de crescimento, na tentativa de elucidar seu modo de ação, quais os principios ativos mais adequados, níveis e consequências para a saúde humana e animal.

\subsubsection{Situação atual sobre o uso de antibióticos como promotores de crescimento}

Atualmente a questão do uso de antibióticos como promotores de crescimento na alimentação animal vem sendo discutida incessantemente em todo o mundo. É um assunto bastante polêmico e controverso. Os dois pontos mais problemáticos que envolvem o uso desses promotores de crescimento é a preocupação com a transferência de bactérias resistentes aos antibióticos para seres humanos e também com a seleção de bactérias resistentes em humanos através de resíduos na carne.

Embora a literatura científica sobre antibióticos promotores de crescimento seja relativamente vasta, existe uma incerteza em relação aos aspectos referentes à saúde humana e animal. Apesar de toda a discussão a respeito da segurança e uso dos promotores de crescimento as decisões e conclusões são tomadas frequentemente sem embasamento científico, mas sobre considerações de ordem política, econômica e social.

$\mathrm{Na}$ União Européia, os promotores de crescimento usados na ração animal são estritamente controlados pela legislação. A Organização Mundial de Saúde (OMS) reafirmou numa conferência realizada em Berlim, Alemanha em 1997 que:"o uso de qualquer promotor de crescimento deve ser proibido se for usado em terapêutica humana" (Erpelding, 1999).

Ainda em 1997 a Europa baniu a avoparcina (Roche) do seu mercado, alegando que o aparecimento de cepas de Enterococcus resistentes a vancomicina (VRE) foi devido ao uso desse antibiótico em animais de produção, resultando numa possivel transferência de resistência ao antibiótico vancomicina. Vancomicina é usada na terapêutica humana há muitos anos, 
sendo eficaz contra Enterococcus os quais causam infeções em pacientes com deficiência imunitária (Mudd, 1997).

No artigo escrito por Mudd (1997), algumas evidências foram relatadas na tentativa de demonstrar que essas especulações poderiam não ter fundamento:

- Avoparcina tem sido amplamente usada nos USA desde 1976 e por quase 15 anos não surgiu nenhuma evidência de problema com VRE.

- Atualmente a VRE tem sido encontrada em animais como cavalos e cães que nunca receberam avoparcina.

Em 1998, mais quatro antibióticos promotores de crescimento foram proibidos na Europa, incluindo: bacitracina de zinco, espiramicina, virginiamicina e fosfato de tilosina (Erpelding, 1999).

No Brasil, já foi banido das rações o uso de nitrofurazona, furazolidona e cloranfenicol (Portaria SDAMA N ${ }^{0} 448$ de 10 de setembro de 1998), avoparcina (Portaria SVS/MS N 819 de 16 de outubro de 1998), penicilina, oxitetraciclina e clortetraciclina como promotores de crescimento (Portaria SVS/MA N 159 de 23 de junho de 1992) (Soncini, 1999).

A preocupação com o uso de antibióticos é cada vez mais evidente, uma vez que somos exportadores de produtos de origem animal e $\circ$ Brasil pode sofrer sanções por estar empregando na alimentação animal drogas proibidas por esses países.

Segundo o Compêndio Brasileiro de Alimentação Animal (1998), os antibióticos e quimioterápicos mais usados atualmente no Brasil como promotor de crescimento são: ácido arsanílico, ácido 3-nitro, avilamicina, bacitracina, BMD, carbadox, colistina, enramicina, flavomicina, halquinol, lasalocida, lincomicina, monensina, nitrovin, olanquidox, tiamulina, tilosina e virginiamicina.

\subsubsection{Resistência bacteriana aos antibióticos}

Em 1957, foi realizada uma conferência (British Veterinary Association), em que foi demonstrado o receio quanto a ocorrência de resistência bacteriana aos antibióticos devido ao uso desses em rações animais (Mckay, 1975). 
Segundo Bird (1968) e Smith (1975) não há dúvidas que o uso de antibiótico resulta numa variedades de organismos intestinais que podem demonstrar resistência aos antibióticos.

Quando se fala de resistência aos antibióticos precisa-se saber como ocorrem, quais os tipos de resistências, quais são as possiveis consequências e o impacto à saúde humana e animal.

Existem vários mecanismos diferentes que podem explicar a resistência bacteriana aos antibióticos. Estes podem ser resumidos como:

1) A bactéria produz enzimas que destróem ou modificam a estrutura do antibiótico.

2) Os antibióticos podem ser incapazes de penetrar na superfície das células bacterianas. Desta forma o antibiótico não pode atuar no sítio suscetível dentro da célula, como os ribossomos.

3) A bactéria pode possuir uma via bioquímica alternativa que desvia a reação particular que é inibida pelo antibiótico.

4) A bactéria pode possuir tipos de enzimas, ribossomos ou outros componentes celulares que não são afetados pelo antibiótico (Pelczar et al., 1996).

Primeiramente são conhecidas duas formas de resistência: intrínseca e adquirida. Intrínseca é um processo de evolução natural, algumas bactérias são normalmente resistentes a determinados antibióticos. Não é transferida para outras bactérias, apenas aos seus descendentes. A outra forma é a adquirida, pode ser através de mutações ou transferência de material genético (Azevedo, 1985).

A mutação é um processo raro e ocorre espontaneamente em uma população mesmo na ausência da droga; o antibiótico então funcionará apenas como agente selecionador de bactérias mutantes. Um segundo mecanismo que leva à variação bacteriana e consequentemente resistência, é a recombinação (transferência de material genético); são três os processos que levam à recombinação bacteriana: 1- conjugação, em que o DNA é transferido por 
contato direto, célula a célula; 2- transformação, vem a ser o processo pelo qual um DNA exógeno é capaz de penetrar em uma célula receptora; 3- transdução, consiste essencialmente da transferência de DNA de uma célula a outra, por meio de bacteriófagos (Azevedo, 1985).

Em comunidades humanas e animais que nunca ou raramente foram expostas aos antibióticos, a incidência de cepas resistentes é extremamente baixa. Somente em comunidades que frequentemente recebem antibióticos é que a incidência de cepas resistentes é alta (Smith, 1975).

A maioria dos casos de resistência bacteriana em seres humanos é decorrente do uso de antibióticos nos próprios seres humanos, uso este inadequado e/ou excessivo em muitas situações (Sindan, 1999).

Como foi descrito anteriormente o gene para resistência pode ser transmitido de uma célula resistente para uma sensivel por meio da conjugação; esse processo foi relatado, pela primeira vez, em 1958, por dois microbiologistas japoneses (Pelczar et al., 1996).

A transferência de resistência parece estar confirmada, principalmente em enterobactérias e outras bactérias aeróbias gram negativas, tais como Proteus e Pseudonomas, as quais habitam o trato alimentar do homem e do animal. Essa resistência pode ser transferida entre organismos da mesma espécie, por exemplo, entre cepas de Escherichia coli, e entre organismos de diferentes espécies, por exemplo E. coli, Shigella e Salmonella (Smith, 1975).

Os genes responsáveis pela resistência de mutação estão localizados no cromossomo bacteriano, aqueles que controlam transferência de resistência estão localizados extracromossomalmente como plasmídeos e são usualmente referidos como fator $R$ (Smith, 1975).

Embora a transferência de resistência seja um evento provável de ocorrer, até agora, todos os estudos epidemiológicos realizados não relataram nenhuma fatalidade humana com o uso de antibióticos como promotores de crescimento na produção animal (Erpelding, 1999). 
A Food and Drug Administration (FDA) (1999) relatou que os efeitos de transferência de resistência de bactérias aos antibióticos de animais para humanos é determinada por uma cadeia complexa de eventos, que incluem: a habilidade da droga em induzir resistência bacteriana; a probabilidade que o uso em animais venha a promover tal resistência; a probabilidade que qualquer bactéria resistente no animal seja transferida aos humanos e a probabilidade que tal transferência resulte em fracasso no tratamento com antibióticos em humanos devido à resistência.

Outra preocupação bastante plausivel é a que se refere aos residuos de antibióticos em produtos de origem animal; estes podem trazer alguns prejuizos para as pessoas que consomem esses produtos. Smith (1975) levantou a hipótese de esses resíduos podem produzir efeitos prejudiciais devido à toxicidade ou reações alérgicas em pessoas que possuem previamente sensibilidade ao antibiótico e também levar ao aparecimento de cepas resistentes de bactéria.

$\mathrm{Na}$ Europa, em março de 1999, a mais extensa revisão científica sobre promotores do crescimento foi liberada pela fundação independente Heidelberg Appel Nederland Foundation. O relatório intitulado "Surgimento de um Debate: AGPs e Saúde Pública", "Saúde Humana e Antibióticos Promotores do Crescimento, AGPs: Reavaliando o Risco"conclui:

- Até o presente momento, o uso de AGP não comprometeu o uso terapêutico humano de antibióticos relacionados.

- Até o momento, os dados epidemiológicos não demonstraram um aumento de doenças infecciosas como resultado do uso de AGPs.

- Em toda a documentação, os casos in vivo, demonstrando a disseminação de bactérias gram positivas resistentes aos antimicrobianos a partir de animais de criação para o homem são essencialmente inexistentes (Erpelding, 1999).

Os antibióticos, para serem aceitos e empregados como promotores de crescimento, devem satisfazer certos requisitos (Benício, 1996; Butolo, 1998):

a) Melhorar o desempenho da maneira efetiva e econômica. 
b) Ser atuantes em pequenas dosagens.

c) Não devem apresentar resistência cruzada com outros microingredientes de alimentação.

d) Não devem ter efeitos deletérios ao ambiente.

e) Não devem ser absorvidos pelo trato gastrointestinal.

f) Não devem estar envolvidos em transferência de resistência.

g) Não devem deixar resíduos na carcaça.

h) Devem permitir a manutenção da flora gastrointestinal normal.

i) Não podem ser tóxicos para os animais e ao ser humano nas dosagens recomendadas.

j) Não podem ser mutagênicos ou carcinogênicos.

\subsubsection{Composição da população microbiana intestinal de uma ave saudável}

A população bacteriana no trato gastrointestinal de aves comerciais é qualitativamente e quantitativamente grande. Após a eclosão, o trato gastrointestinal é rapidamente colonizado (March, 1979). Salanitro et al. (1978) observou que nos primeiros 4 dias o intestino delgado e o ceco de aves são particularmente colonizados por Streptococcus e Enterococcus .

Aproximadamente $85 \%$ dos organismos isolados do duodeno, íleo e ceco são gram positivos. A maioria das bactérias do intestino delgado são anaeróbias facultativas, ao passo que as bactérias anaeróbias estritas incluem a maior parte da microflora cecal (Tabela 1) (Salanitro et al., 1978). 
Tabela 1. Distribuição de bactérias intestinais em frangos de corte.

\begin{tabular}{|c|c|c|c|c|}
\hline \multirow{2}{*}{$\frac{\text { Bactéria }}{\text { Nome }}$} & \multicolumn{4}{|c|}{ Partes do intestino } \\
\hline & Duodeno & Jejuno & Tíleo & Ceco \\
\hline Streptococcus & 36,6 & 8,9 & 16,8 & 0,7 \\
\hline Stafilococcus & 0,4 & - & 0,5 & - \\
\hline Lactobacillus & 19,0 & 33,8 & 59,0 & - \\
\hline Escherichia Coli & 5,4 & 33,0 & 14,7 & - \\
\hline Anaeróbios coccus & 1,8 & 0,9 & 0,5 & 14,2 \\
\hline Eubacterium & 26,4 & 22,6 & 7,8 & 60,6 \\
\hline Propionibacterium & 0,3 & 0,4 & - & - \\
\hline Clostridium & 1,8 & 0,4 & - & 2,1 \\
\hline Gemminger & 1,5 & - & - & 3,4 \\
\hline Fusobacterium & 3,7 & - & 0,5 & 6,2 \\
\hline Bacteroides & - & - & - & 12,8 \\
\hline Anaeróbios facultativos & 61,4 & 75,7 & 91,0 & 0,7 \\
\hline Anaeróbios & 38,6 & 24,3 & 9,0 & 99,3 \\
\hline
\end{tabular}

Adaptado de Salanitro et al., 1978.

A microflora no trato gastrointestinal é responsável por importantes funções no organismo da ave. No papo está presente uma população de Lactobacillus que podem trazer benefícios a ave, pois, controlam a multiplicação de bactérias menos desejáveis através da redução do pH (March, 1979). Acredita-se que quantidade significativa de amido seja digerido no papo do frango como resultado da ação bacteriana (Dukes, 1993).

Existem algumas bactérias normalmente presentes no trato que possuem a capacidade de sintetizar vitaminas do complexo B e vitamina K (March, 1979).

A presença da flora não patogênica no trato digestivo afeta a absorção de ácidos graxos de cadeia longa, como o palmítico e esteárico. Alguns microorganismos possuem a habilidade de desconjugar e dehidroxilar os sais biliares (MacNab, 1973).

Normalmente a flora microbiana se encontra em equilibrio e qualquer mudança nesta proporção é potencialmente causadora de baixa performance produtiva e infecções intestinais. Provavelmente bactérias patogênicas estão presentes no intestino por toda a vida da ave, mas somente quando surge uma 
circunstância que altera o ambiente a seu favor é que ocorre a proliferação até um número suficiente para produzir um sintoma clínico (March, 1979).

Alguns fatores como idade, resposta imune, dieta, administração oral de antibióticos e quimioterápicos podem ser responsáveis pela alteração da flora intestinal normal (Soares, 1996).

\subsubsection{Antibióticos e a sua importância na ativação do sistema imune}

$O$ efeito benéfico dos promotores de crescimento no desempenho das aves depende de vários fatores, tais como a composição e concentração do produto na ração, período de fornecimento da droga, princípio ativo, manejo, idade, condições ambientais e sanitárias das instalações (Gomes, 1991).

Em ensaios realizados em galpões experimentais, onde o ambiente é mais controlado, melhor higienizados, observa-se menor resposta aos promotores de crescimento do que em condições de campo; isto pode ser devido ao maior desafio microbiano a que esses animais são submetidos. Hill et al. (1952) testaram dietas com ou sem adição de penicilina em lotes de frangos criados em dois ambientes diferentes. Em um deles as instalações eram novas e limpas e no outro as instalações já tinham sido usadas por vários anos, estando velhas e sujas. A resposta no ganho de peso na quarta semana de idade com o uso de antibióticos foi cerca de $8 \%$ maior para aquelas aves criadas em ambiente sujo quando comparadas com as criadas em ambiente limpo.

Segundo Stahly, citado por Rostagno \& Silva (1998) a magnitude da resposta de crescimento de suínos aos promotores de crescimento é influenciada pelo nível de exposição a antígenos. Quanto maior for o desafio microbiano a que os animais são expostos, maiores serão as respostas obtidas pelo uso de antimicrobianos nas rações

Desafio microbiano é uma forma comum de estresse encontrado nos animais em crescimento, podendo ou não resultar em doenças clínicas,

${ }^{2}$ Stahly, T. S. The role of antimicrobial agents in lean pork production. (Trabalho apresentado no:

ANNUAL PFIZER RESEARCH CONFERENCE, 43, 1995) 
dependendo da patogenicidade dos microrganismos e da imunocompetência do animal. As mudanças no metabolismo seguidas por um tipo de resposta inflamatória desencadeada pelo sistema imune tem sido referida como estresse imunológico (Klasing et al., 1987).

Depois da indução da resposta imune pelo antígeno, leucócitos transmitem sinais não somente para os muitos componentes do sistema imune mas também para o cérebro e órgãos neuroendócrinos. $O$ sinal envolve citoquinas e proteínas hormonais clássicas elaboradas e liberadas pela células imunes (Kelley et al., 1993).

Uma ave desafiada imunologicamente produz diversas citoquinas que podem aumentar a taxa metabólica aumentando a temperatura corporal, causar anorexia e até mesmo direcionar os nutrientes para atender às necessidades energéticas da resposta imune, em vez de crescimento muscular (Ferket, 1999). Essas respostas fisiológicas são provavelmente ativadas e coordenadas pelo cérebro na tentativa de oferecer condições ao organismo para "lutar" contra a invasão de agentes patogênicos (Kelley et al., 1993).

O sistema imune nas aves é dependente de três tipos de células: macrófagos, linfócitos $B$ e linfócitos T. Todos estes tipos de células imunes, interagem em resposta a um agente infeccioso ou a um antígeno. O macrófago detecta, ingere (fagocita) e digere o agente infeccioso e apresenta o antígeno aos linfócitos B e T. O macrófago também manda um sinal (interleucina-1 ou IL1) que estimula as células $T$ auxiliares a liberar outro mediador, a interleucina-2, que faz com que o número de células $T$, específicas para aqueles antígenos em particular, aumente. Sinais adicionais das células $T$ estimulam a produção de células $B$ específicas para o antígeno. A IL-1 também estimula as células pré-B e a expansão clonal das células $B$ maduras, que produzem anticorpos específicos aos antígenos (Ferket, 1999).

A IL-1 é um mediador das mudanças imunológicas que envolvem estresse imunológico. Portanto a IL-1 aumenta quando aumenta a produção de anticorpos e esta aumenta em situações em que o sistema imune é ativado; em 
animais saudáveis isso ocorre quando submetidos a desafios microbianos, ou simplesmente quando expostos as altas concentrações de agentes não patogênicos, como por exemplo poeira e estresse.

Roura et al. (1992) estudaram a relação entre o efeito do uso de antibiótico como promotor de crescimento e o estresse imunológico avaliados pela medição dos niveis de IL-1 no plasma. Utilizaram 72 pintos de corte com 3 dias de idades e forneceram dois tipos de dieta, uma sem antibiótico e outra com $200 \mathrm{mg} / \mathrm{kg}$ de uma mistura 1:1 de penicilina e estreptomicina, alojados em dois ambientes, um limpo e outro sujo. Depois de 14 dias foram retiradas amostras de sangue de todas as aves para quantificar a concentração de IL-1 no plasma. As concentrações de IL-1 foram maiores em frangos criados em ambiente sujo do que em frangos criados em ambiente limpo $(P<0,05)$. Em frangos criados em ambiente limpo, o uso de antibióticos não afetou as concentrações de IL-1. O nivel de IL-1 dos frangos alojados em ambiente sujo recebendo antibiótico foi bem menor $(50,4 \%)$ quando comparados com frangos em mesmo ambiente sem antibióticos.

A IL-1 é uma citoquina que pode ativar a febre que é classicamente definida pelo aumento na temperatura corporal (Kelley et al., 1993). A febre é considerada o primeiro sinal de manifestação da resposta imune. Em mamíferos, a IL-1 provavelmente é responsável pelo aumento da temperatura corporal após injeção de imunogênicos. A correlação entre IL-1 e temperatura corporal foi demonstrada não somente em mamíferos, mas também em aves (Klasing et al., 1987). De acordo com Beisel ${ }^{3}$, citado por Klasing et al. (1987) o aumento na taxa do metabolismo basal devido a febre é cerca de $10-15 \%$ por grau centígrado aumentado.

Klasing et al. (1987) estudaram a influência da IL-1 e corticosteróides (Cort) no desempenho de frangos de corte em situações de desafio microbiano. Injetaram intraperitonealmente (i.p.) solução salina estéril, preparação bruta de

${ }^{3}$ Beisel, W. R. (1977) Magnitude of host nutrition response to infection. Am. J. Clin. Nutr. 30:1236-1247 
IL-1, IL-1 inativa, Cort $(500 \mu \mathrm{g} / \mathrm{kg})$ ou Lipopolissacarídeo $(100 \mu \mathrm{g})(\mathrm{LPS}$ E. coli $=$ imunoativador) em 8 frangos por tratamento aos 9 dias de idade. Foi avaliada a temperatura corporal através da tomada da temperatura cloacal 2 horas após injeção nos dia 1, 3 e 6 . A IL-1 e LPS induziram uma resposta febril $(42,5$ e $42,3^{\circ} \mathrm{C}$, respectivamente) quando comparado com a solução salina $\left(41,5^{\circ} \mathrm{C}\right) . \mathrm{O}$ Cort não influenciou a temperatura cloacal.

Roura et al. (1992) alimentaram frangos de corte de um dia com dietas basais com ou sem $100 \mathrm{mg} / \mathrm{kg}$ de tetraciclina por 15 dias, sendo que a metade dos frangos de cada gaiola aos 15 dias de idade receberam LPS de Salmonella thiphimurium (100 mg/L) intraperitonialmente; 4 horas depois da injeção foi medida a temperatura cloacal de um frango injetado e de um não injetado de cada gaiola. Verificaram aumento de $0,30^{\circ} \mathrm{C}$ na temperatura retal dos frangos que receberam a injeção quando comparados com aqueles que não receberam. Semelhantemente, os frangos que não foram alimentados com dietas com antibióticos também tiveram maiores temperaturas $\left(0,23^{\circ} \mathrm{C}\right)$ do que aves que receberam antibiótico na ração.

Várias pesquisas relatam que o aumento de peso devido aos agentes antimicrobianos é mais evidente durante o período de rápido crescimento, com diminuição posterior. Animais mais jovens respondem melhor ao uso de antibióticos pelo fato de serem mais suscetiveis aos patógenos, porque possuem baixa proteção imunológica.

\subsubsection{Efeitos da virginiamicina}

Desde os anos 50 a virginiamicina (VM) vem sendo estudada como promotor de crescimento e há muitos anos tem o seu uso largamente difundido na criação zootécnica.

A VM é um antibiótico complexo, amorfo, pó branco, solúvel em metanol, etanol, acetona, benzeno e clorofórmio, produzido por Streptomyces virginae. É uma mistura de dois principais componentes: Fator $\mathrm{M}\left(\mathrm{C}_{28} \mathrm{H}_{35} \mathrm{~N}_{3} \mathrm{O}_{7}\right)$ e Fator $\mathrm{S}$ $\left(\mathrm{C}_{43} \mathrm{H}_{49} \mathrm{~N}_{7} \mathrm{O}_{10}\right.$ ). O Fator $\mathrm{M}$ aparece em maior quantidade, cerca de $75 \%$, e é eficaz principalmente contra Micrococcus aureus, enquanto o Fator $S$ é eficaz 
contra Bacillus subtilis e entra na porcentagem de 5\% na mistura (Merk Index, 1985). Juntos, os dois componentes agem de forma sinérgica mostrando largo espectro de ação contra organismos gram positivos e sua ação antibacteriana parece estar relacionada com a inibição da síntese protéica.

$O$ fato de a VM agir quase que exclusivamente em bactérias gram positivas torna-a de grande importância, pois acaba quase que completamente com o perigo da transferência da resistência à droga. A VM pode ser associada com qualquer gram negativo, o que torna o seu uso bastante interessante (Jong et al., 1985).

A VM, além de possuir má absorção, é eliminada praticamente intacta pelas fezes, ou seja tem um pequeno efeito residual (Miles et al., 1984). Gomes, 1991 relatou que antibióticos não absorvidos pelo intestino são de menor importância na terapia humana, mas podem ser amplamente utilizados para promoção do crescimento e controle de doenças entéricas nos animais.

O nivel de energia das dietas parece influenciar a resposta aos antimicrobianos. March et al. (1978) puderam constatar em seu experimento que a suplementação de VM em dietas para frangos de corte proporcionou aumento médio de $7,2 \%$ no valor de EM das dietas que gerou em torno de $3220 \mathrm{EM} \mathrm{kcal} / \mathrm{kg}$. Ainda neste experimento foi observado aumento médio significativo no peso vivo de $10,3 \%$ aos 26 dias e $5,0 \%$ aos 53 dias de idade. A conversão alimentar também foi melhorada significativamente.

Miles et al. (1984) detectaram diferença significativa na performance de frangos suplementados com $10 \mathrm{ppm}$ de VM. A melhora no ganho de peso e eficiência alimentar foi da ordem de $2,3 \%$ e 1,8\%, respectivamente em relação as aves não suplementadas e não houve diferença significativa na mortalidade.

Jong et al. (1985), estudando o efeito do uso de avoparcina e virginiamicina como promotores de crescimento sobre o desempenho produtivo e utilização da energia da ração em frangos de corte, concluíram que a adição de antibióticos às rações não afetou o consumo de ração nem o ganho médio de peso das aves, mas melhorou a conversão alimentar e aumentou a 
eficiência de utilização de energia da ração (medida através da determinação da energia metabolizável).

Izart et al. (1989) conduziram dois experimentos para avaliar o efeito da suplementação de VM (11 ppm) e bacitracina $(27,5 \mathrm{ppm})$ sobre o rendimento de carcaça de frangos machos e fêmeas. Os pesquisadores observaram que as dietas que continham qualquer um dos dois antibióticos levaram a uma pequena queda no rendimento de carcaça para os machos, mas não para as fêmeas.

Bertechini \& Hossain (1992), considerando o período total de criação de frangos de corte ( 1 - 44 dias), verificaram que os resultados de desempenho foram estatisticamente semelhantes quando se utilizou VM, probiótico ou a associação dos dois, sendo que a não utilização desses microingredientes de alimentação resultou em piores ganho de peso e conversão alimentar.

Zhong et al. (1995), estudando o efeito de virginiamicina $(5,10,20 \mathrm{mg} / \mathrm{kg}$ ) e bacitracina de $\mathrm{Zn}(20 \mathrm{mg} / \mathrm{kg}$ ) como promotores de crescimento em frangos de corte, obtiveram aumento no ganho de peso na ordem de 2,2, 5,4, 5,1 e 2,5\% respectivamente e na eficiência de conversão alimentar aumento de $1,3,4,3$, 4,3 e $1,3 \%$ respectivamente. Concluíram que a suplementação com a virginiamicina nas dosagens 10 e $20 \mathrm{mg} / \mathrm{kg}$ proporcionaram um efeito promotor do crescimento.

\subsection{COBRE}

\subsubsection{Importância, exigência nutricional e toxicidade do cobre}

O cobre é um micromineral essencial para animais e vegetais, sendo um constituinte de todas as células. Foi descoberto como um importante elemento nutricional no início do século $X X$, em consequência de uma série de estudos iniciados em 1925; Hart e auxiliares na Universidade de Wisconsin descobriram que uma diminuta parcela de cobre é necessária, juntamente ao ferro, para a formação da hemoglobina em ratos. (Coutinho,1981; Maynard et al., 1984; Andriguetto et al., 1991). 
O cobre faz parte de diversos sistemas enzimáticos. Entre eles, as tirosinases, presentes em muitos tecidos animais e vegetais. Catalisam a oxidação da L-tiroxina a 3,4 - dihidroxi - $L$ fenilalanina (DOPA) e a oxidação posterior da DOPA a pigmentos melanínicos (Coutinho, 1981). A pigmentação dos cabelos, pelos, lã e pele dos homens e animais depende da presença de cobre, pois o mesmo faz parte da enzima polifenil-oxidase que catalisa a produção de melanina (Andriguetto et al., 1991). Outras enzimas como lactase, ácido ascórbico-oxidase plasmática, eritrocupreína, uricase, lisil oxidase, benzilamina oxidase e diamina oxidase e superóxido-desmutase contêm cobre, e sua atividade é dependente desse elemento (Coutinho,1981; Maynard et al., 1984 Dukes, 1993).

O cobre é necessário para o metabolismo do ferro, favorecendo a sua reabsorção no intestino, bem como a mobilização do mesmo dos tecidos para o plasma, estimulando assim a síntese de hemoglobina. Admite-se que o ferro é absorvido como $\mathrm{Fe}^{2+}$ e transportado como $\mathrm{Fe}^{3+}$ e que a conversão exige uma enzima que é dependente de cobre, como ferroxidase II. O cobre participa ainda na mineralização dos ossos, formação da integridade do miocárdio e do sistema nervoso central (Andriguetto et al., 1991).

Animais com deficiência de cobre apresentam acromotriquia, embranquecimento dos pelos dos gatos, bovinos, caprinos e ovinos. (Coutinho, 1981). Outros problemas associados à deficiência são a anemia, alterações ósseas, ataxia neonatal, despigmentação e crescimento anormal de pelos e lã, alterações no crescimento e desempenho reprodutivo, insuficiência cardiaca e distúrbios gastrointestinais (Dukes, 1993).

A exigência dietética de cobre é afetada pelo nível de certos outros minerais na alimentação (Andriguetto et al., 1991). Excesso de molibdênio poderá ocasionar deficiência de cobre (Maynard et al., 1984). O manganês administrado em altas doses forma um complexo com o cobre que bloqueia a ação de enzimas cúpricas, provocando a redução da eliminação urinária do elemento, determinando uma anemia microcítica hipocrômica (Andriguetto et al, 
1991). O National Research Council, 1994 (NRC) considera a exigência de 8 $\mathrm{mg}$ de cobre/kg para frangos de corte.

Quando o cobre é ingerido em altas doses poderá ser tóxico. A severidade da intoxicação depende de vários fatores como a espécie animal, a forma química do cobre ingerido e os teores de outros minerais como, $\mathrm{Fe}, \mathrm{Mo} e$ $\mathrm{Zn}$ (Andriguetto, 1991). Várias pesquisas foram realizadas para determinar o nivel tóxico de cobre (Mehring et al., 1960; Funk \& Baker, 1991). Atualmente valores acima de $250 \mathrm{ppm}$ são considerados tóxicos para frangos de corte (NRC, 1994). Jensen \& Maurice (1978) encontraram problemas de erosão na moela de frangos de corte alimentados com altos níveis de sulfato de cobre (240 ppm de cobre/ kg de ração); a severidade da erosão piora quanto maior o nível de cobre adicionado a ração (Poupoulis \& Jensen, 1976).

\subsubsection{Absorção e excreção do cobre}

O mecanismo de absorção de cobre no trato gastrointestinal é relativamente pouco conhecido (Starcher et al., 1969). Nos animais monogástricos, o cobre é absorvido principalmente na parte superior do intestino delgado, onde o pH do conteúdo é ácido (Dukes, 1993). Em suínos a absorção de cobre ocorre no intestino delgado e cólon e em aves no estômago e no intestino delgado (Andriguetto et al., 1991).

Starcher et al. (1969), num estudo sobre mecanismo de absorção de cobre em frangos, concluíram que a absorção de cobre é muito maior no duodeno do que no estômago. A absorção de cobre no intestino requer um mecanismo especifico, devido à alta insolubilidade dos íons de $\mathrm{Cu}^{++}$. Através da mucosa gástrica é secretada uma substância que complexa com o $\mathrm{Cu}^{++}$ tornando-o solúvel no pH do fluido intestinal (Bertechini, 1994). Starcher et al. (1969) encontraram presente na mucosa duodenal cobre radioativo $\mathrm{Cu}^{64}$ firmemente e especificamente complexado com uma proteína. No intestino a absorção de cobre é semelhante à do zinco, havendo até competição pelos mesmos sítios promotores das proteínas que absorvem e transportam este 
elemento (Starcher et al, 1969; Bertechini, 1994). O cádmio e o zinco são considerados antagonistas ao cobre (Starcher et al., 1969).

A disponibilidade do cobre é baixa para a maioria dos animais, sendo a sua absorção de 5 a 10\% do ingerido (Coutinho, 1981; Andriguetto et al., 1991; Dukes 1993). A absorção depende da forma química pela qual é administrado, do nivel dietético de outros minerais, substâncias orgânicas e finalmente, depende da acidez do conteúdo intestinal na área de absorção (Andriguetto et al., 1991).

O cobre, assim que é absorvido, se concentra no fígado que é o principal órgão envolvido no seu metabolismo (Coutinho, 1981); nele o cobre é incorporado às mitocôndrias, microssomos, núcleo e à fração solúvel das células do parênquima hepático. É armazenado na eritrocupreína, ceruloplasmina ou nas várias enzimas que contém cobre (Andriguetto et al., 1991). O cobre volta ao plasma como cobre da ceruloplasmina (Coutinho, 1981).

Em condições normais, $90 \%$ ou mais do cobre ingerido aparece nas fezes. A maior parte do cobre fecal é inabsorvida da dieta, mas alguma parte dele provém da bile, que é a sua principal via de excreção. (Coutinho, 1981; Dukes, 1993).

\subsubsection{Efeito de altas doses de cobre e suas fontes}

O cobre quando é suplementado em níveis bem acima do exigido nutricionalmente possui a função de promotor de crescimento. $O$ primeiro relato indicando que a adição de sulfato de cobre à ração de suínos em crescimento melhorou o desempenho dos animais data de 1955, na Inglaterra (Braude ${ }^{4}$, citado por Menten, 1995). Alguns anos depois, a ação promotora do crescimento proporcionada pelo cobre também foi observada em frangos de corte.

\footnotetext{
${ }^{4}$ Braude, R. Cooper as stimulant in pig feeding (Cuprum propecunia) World Rev. Anim. Prod., Roma, 3:69-81, 1967.
} 
Procurou-se estudar a viabilidade da utilização do cobre como promotor do crescimento como uma alternativa aos antibióticos, devido aos possíveis problemas acarretados por eles e pelo maior custo quando comparado com o cobre. Vários estudos foram realizados comprovando a eficiência deste elemento como promotor de crescimento e surgiu o interesse em se avaliar em diversas fontes de cobre, como os sulfatos, carbonatos, cloretos, óxidos e complexos orgânicos de cobre.

$O$ sulfato de cobre pentahidratado $\left(\mathrm{CuSO}_{4} \cdot 5 \mathrm{H}_{2} \mathrm{O}\right)$, a fonte mais comumente usada, é um composto de cor azul, que pode apresentar-se na forma de grandes cristais, grânulos azuis, ou ainda, como um pó azul claro; possui cerca se $25 \%$ de cobre (Merk Index, 1985).

Stansbury et al. (1990) compararam o sulfato de cobre com duas formas quelatadas de cobre, uma orgânica e outra inorgânica. Foi avaliado a performance de suinos na fase de creche ( 6 a $25 \mathrm{~kg}$ ) e crescimento (20 a 65 $\mathrm{kg}$ ). Não houve diferença no desempenho dos suínos; os autores justificaram que a dose estudada (125 ppm) não é a recomendada para a promoção do crescimento. Num segundo experimento foi confirmado que a dose mais efetiva foi 250 ppm. Houve interação $(P<0,01)$ entre fonte e nivel, mas apenas para a variável conversão alimentar, sendo que a fonte sulfato de cobre com 250 ppm proporcionou melhores resultados quando comparado com os niveis da fonte quelatada inorgânica. Nenhuma diferença foi detectada quando a fonte quelatada orgânica foi comparada com o sulfato de cobre. Esses experimentos indicaram pequena ou quase nenhuma diferença na forma de quelatos e sulfato de cobre na performance de suinos na fase de creche e crescimento.

Baker et al. (1991) compararam quatro fontes de cobre, usando o sulfato de cobre como padrão. Baseando-se no acúmulo de cobre no fígado, concluíram que as fontes $\mathrm{Cu}_{2} \mathrm{O}$ e o complexo $\mathrm{Cu}$-lisina foram tão eficiente quanto o sulfato, mas o $\mathrm{CuO}$ não teve boa biodisponibilidade.

Ledoux et al. (1991), estudando a biodisponibilidade de fontes inorgânicas de cobre e o efeito no desempenho de frangos de corte observaram que os 
níveis de 150,300 ou $450 \mathrm{mg}$ de Cu/kg de ração não tiveram efeito nas variáveis estudadas. Entretanto, as aves que foram alimentadas com acetato de cobre tiveram menor consumo de alimento $(P<0,01)$ e menor ganho de peso $(P<0,01)$ do que as aves que receberam as demais fontes (óxido, sulfato e carbonato de cobre). A conversão alimentar não foi afetada pela fonte ou pelos níveis estudados.

Hoda \& Maha (1995), estudando o cobre como promotor do crescimento em frangos de corte em três fontes distintas (carbonato, óxido e sulfato de cobre) e três níveis (0,75 e $150 \mathrm{mg}$ de Cu/kg de ração), detectaram aumento no ganho de peso com os dois níveis de suplementação de carbonato de cobre e melhora na eficiência de conversão alimentar. A fonte sulfato de cobre conduziu à melhores resultados com $150 \mathrm{mg}$ do que com $75 \mathrm{mg} / \mathrm{kg}$. O óxido de cobre não afetou o desempenho das aves. O cobre no fígado não foi afetado por nenhum tratamento.

Coffey et al.. (1994) conduziram oito experimentos comparando a eficácia da suplementação do complexo cobre-lisina (CU-LYS) em dietas para leitões. Em três experimentos dos oito relatados pelos autores, o complexo CU-LYS foi mais efetivo em melhorar a performance dos animais do que o sulfato de cobre; nos demais experimentos ambas as fontes proporcionaram uma eficiência equivalente. Estes achados são contrários aos resultados de pesquisa realizado por Apgar et al. (1995), que não observaram diferença entre complexo CU-LYS e sulfato de cobre na performance de leitões. O ganho de peso e o consumo alimentar aumentaram linearmente $(P<0,01)$ com aumento nos niveis de cobre (100, 150 e $200 \mathrm{mg}$ de Cu/kg de ração) independente da fonte utilizada.

O complexo CU-LYS é um produto orgânico composto de um íon de cobre ligado ao aminoácido lisina. Algumas pesquisas tem demonstrado efeito positivo no crescimento, quando o complexo CU-LYS é adicionado em dietas de suínos (Apgar \& Kornegay, 1996; Zimpro, 1999). O complexo CU-LYS é mais biodisponivel que o sulfato de cobre, indicando que pode-se esperar um 
crescimento animal similar em niveis mais baixos de cobre do que aqueles encontrados com o sulfato de cobre.

Recentemente a fonte cloreto de cobre tribásico foi testada em suínos (Cromwell et al., 1998) e em frangos de corte (Milles et al., 1998) e foi demonstrado que o cloreto de cobre tribásico é tão efetivo quanto o sulfato de cobre para melhorar o crescimento desses animais.

Devido ao custo relativamente baixo, o cobre tem sido largamente utilizado em dietas de suínos, muitas vezes sem critérios científicos. Recomenda-se que os niveis utilizados desse mineral e os programas de alimentação que faz uso deste promotor de crescimento sejam revistos devido aos problemas ambientais que eles acarretam (Lima, 1996).

O uso de altas doses de cobre em dietas para frangos de corte resulta em grandes quantidades deste mineral na cama de frango, devido a baixa taxa de absorção pela ave restringindo o seu aproveitamento. A cama de frango apresenta uma boa alternativa como fonte de proteína para a alimentação de outros animais, principalmente de bovinos. Além disso, pode ser utilizada na adubação de lavouras. O acúmulo de resíduo de cobre pode acarretar problemas de toxicidade inviabilizando o seu uso, tanto na alimentação animal como fertilizante na agricultura.

Mesmo com a comprovação que o cobre é um eficiente promotor de crescimento, tanto para aves como suínos, é importante que seu uso seja limitado. É necessário que se estudem novas fontes de cobre que permitam que em uma menor quantidade utilizada do composto possa atingir resultados de desempenho tão bons ou melhores que os proporcionados pelo sulfato de cobre.

Pesti \& Bakalli (1996) realizaram vários experimentos em que utilizaram duas fontes de cobre, o sulfato de cobre pentahidratado e o citrato cúprico. Concluíram que o citrato cúprico foi eficiente como promotor de crescimento em níveis mais baixos de cobre (63 ou $75 \mathrm{mg} / \mathrm{kg}$ ) do que o sulfato de cobre pentahidratado (125 ou $250 \mathrm{mg} / \mathrm{kg}$ ). O uso do citrato cúprico em níveis mais 
baixos de cobre proporcionou além de um melhor desempenho, também uma diminuição do mineral na cama.

Ewing et al. (1998) alimentaram frangos de corte com três fontes de cobre (sulfato de cobre pentahidratado, oxicloreto de cobre e citrato de cobre), observaram que a fonte citrato de cobre, mesmo em níveis menores, proporcionou maior ganho de peso e melhor conversão alimentar do que as demais fontes.

Brainer (1998), testando o efeito do citrato cúprico como promotores de crescimento em frangos de corte, constataram que nas condições em que foi realizado o experimento não houve diferença significativa entre as duas fontes de cobre estudadas (citrato de cobre $75 \mathrm{mg} / \mathrm{kg}$ e sulfato de cobre pentahidratado $200 \mathrm{mg} / \mathrm{kg}$ ) e também não houve efeito do citrato de cobre nas diferentes fases de crescimento (1-21, 22-42, 1-42 dias). Apenas houve diferença em relação ao resíduo de cobre na cama; o uso de citrato cúprico resultou em menor acúmulo na cama quando comparado com o sulfato de cobre.

O citrato cúprico é uma forma orgânica do cobre, cuja fórmula química é $\mathrm{C}_{6} \mathrm{H}_{4} \mathrm{CuO}_{7}$, $\mathrm{O}$ qual pode apresentar-se na forma hemipentahidratado, contendo $35 \%$ de cobre ou na forma anidra com $40,32 \%$ de cobre, com coloração verdeazulada (Merk Index, 1985).

Morais (1999), testando o efeito do citrato cúprico como promotor do crescimento, não observou efeito significativo no desempenho dos frangos de corte. A ausência de resposta foi atribuída ao fato dos animais controle terem bom desempenho e pelas boas condições sanitárias em que as instalações experimentais se encontravam, depois de um longo vazio sanitário e uma cuidadosa desinfeção. Acredita-se que não houve nenhum desafio e por isso o cobre não conseguiu expressar a sua ação promotora do crescimento.

Johnson et al. (1985) avaliaram o efeito de dietas contendo cobre na população microbiológica da cama e no desempenho dos frangos através de quatro experimentos consecutivos sem trocar a cama. Observando os ganhos 
de peso obtidos na fase inicial relataram que não houve diferença significativa no desempenho das aves no experimento 1 e 2 . Entretanto houve uma melhora de aproximadamente $3 \%$ no experimento 3 e $2 \%$ no experimento 4 para as aves que receberam suplementação com $\circ$ sulfato de cobre $(125 \mathrm{mg} / \mathrm{kg})$ quando comparadas com o controle (sem adição de cobre). Os pesquisadores observaram que no decorrer dos experimentos a densidade de fungos na cama diminuía com o aumento da concentração de cobre na cama. Talvez este fator tenha contribuído para um melhor desempenho das aves dos experimentos $3 \mathrm{e}$ 4.

\subsection{EFEITO SINÉRGICO}

A associação entre drogas ou suplementos de enzimas e alto nivel de cobre pode resultar em melhora no desempenho de animais, quando comparado com estes produtos usados isoladamente, se caracterizando o efeito sinérgico (Stahly et al., 1980). Entretanto o uso destes produtos podem dar efeitos semelhantes a antibióticos e assim reduzir ou eliminar a resposta a uma suplementação de antibiótico.

Menten (1995) sugeriu que o efeito sinérgico proporcionado pelos agentes antimicrobianos quando associados pode ser explicado do ponto de vista do modo de ação desses microingredientes, uma vez que diferentes mecanismos de ação estejam atuando de forma independente e simultaneamente. Num experimento com leitões desmamados (30 dias de idade) foram testados três agentes antimicrobianos e sua combinação. $O$ autor verificou o efeito sinérgico no ganho diário de peso (GDP) (365 g para cobre, $379 \mathrm{~g}$ para tiamulin, sulfametazina e furazolidona (TIAM) e $432 \mathrm{~g}$ para a combinação cobre + TIAM) e na conversão alimentar (CA) (1,76 para cobre, 1,70 para TIAM e 1,61 para cobre + TIAM) quando analisado o período total (28 dias). A associação entre cobre e outro microingrediente (carbadox) não resultou em efeito sinérgico no GPD ou na CA. Foi concluído que associação de agentes antimicrobianos no tratamento cobre + TIAM promoveu um marcante efeito sinérgico no 
desempenho dos leitões, constituindo-se em um modelo adequado para estudos a respeito do modo de ação desses microingredientes.

Num segundo ensaio foi verificado que o microingrediente à base de tiamulin causou uma redução de $12 \%(P<0,01)$ no peso do trato gastrointestinal, não havendo efeito de alto nível de cobre. O índice mitótico (\% de células em mitose) no epitélio das criptas foi reduzido em $14 \%(P<0,01)$ pelo alto nível de cobre, sem efeito de tiamulin. $O$ efeito sinérgico no desempenho observado pode ser devido aos efeitos independentes dos microingredientes sobre o peso gastrointestinal e sobre a taxa de reposição do epitélio intestinal.

Cromwell (1991) sumarizou dados de 14 experimentos envolvendo 1.700 suínos ( 7 a $18 \mathrm{~kg}$ ), observando o efeito da adição simples ou combinada de antibióticos e sulfato de cobre na performance dos leitões. Verificou que o uso combinado destes microingredientes proporcionou uma melhora de $31 \%$ no ganho de peso e $12 \%$ na $\mathrm{CA}$ e quando os microingredientes foram testados isoladamente a resposta aumentou apenas cerca de $17 \%$ e $8 \%$, respectivamente.

Milles et al. (1996) estudaram o uso de duas dietas controle, uma à base de milho e farelo de soja (M+S) e a outra com trigo e farelo de soja ( $T+S)$, com a suplementação de virginiamicina $10 \mathrm{mg} / \mathrm{kg}$ ou enzima $1000 \mathrm{mg} / \mathrm{kg}$ Avizyme e/ou o efeito sinérgico entre os dois aditivo com a ração basal $(T+S)$. Observaram que a dieta $T+S$ adicionada da enzima e a dieta $T+S$ adicionada da enzima mais virginiamicina proporcionaram os melhores desempenhos nas aves.

Henrique et al. (1998) testaram o efeito da suplementação de dietas com diferentes antibióticos e probióticos e a combinação entre eles sobre o desempenho e o rendimento de carcaça de frango de corte. Observaram que o uso de antibiótico proporcionou um aumento significativo na mortalidade e o probiótico reduziu a mesma em relação ao controle. Não houve influência do uso de antibiótico e probiótico sobre o desempenho e rendimento de carcaça de frangos de corte. 


\section{MATERIAL E MÉTODOS}

\subsection{Local}

O experimento foi conduzido nas instalações do aviário experimental do Departamento de Produção Animal da Escola Superior de Agricultura "Luiz de Queiroz" Universidade de São Paulo, localizado no município de Piracicaba, Estado de São Paulo, cuja altitude é de $546 \mathrm{~m}, 22^{\circ} 42^{\prime} 30^{\prime \prime}$ de latitude Sul e $47^{0} 38^{\prime} 30^{\prime \prime}$ de longitude Oeste (Ometto, 1989).

\subsection{Aves, Delineamento e Período Experimental}

Foram utilizados 1.200 pintos de corte da linhagem Ag Ross, machos, com um dia de idade, provenientes do incubatório comercial Pena Branca localizado na cidade de São Carlos/SP.

O delineamento experimental foi em blocos casualizados, devido a heterogeneidade da temperatura ambiental no interior do galpão experimental; constituído por cinco tratamentos com seis repetições e 40 aves por unidade experimental. O periodo experimental foi do $1^{0}$ ao $42^{0}$ dia de idade das aves, com início no dia 05/11/1998 e término em 17/12/1998. 


\subsection{Instalações, Preparação e Condução do Experimento}

O galpão experimental (Apêndice 8) está disposto na orientação noroeste-sudeste, com as seguintes dimensões: $32 \mathrm{~m}$ de comprimento por $8 \mathrm{~m}$ de largura e $3 \mathrm{~m}$ de pé-direito. As muretas laterais são de alvenaria com 0,6 $\mathrm{m}$ de altura, piso de concreto, lanternim, cobertura em telhas de barro tipo francesa, telado lateralmente até o teto, equipado com cortinas laterais e duas portas de acesso, uma na frente e outra no fundo. $O$ galpão possui 30 boxes dispostos em três fileiras longitudinais de dez boxes cada, separados por corredores com 1,0 metro de largura. Cada box mede 2,5 m x 2,0 m (5,0 $\left.\mathrm{m}^{2}\right)$, com divisórias de tela de arame estruturado em madeira com 1,70 m de altura e possui uma porta lateral de acesso.

O experimento foi instalado, sobre a mesma cama já utilizada em outro ciclo de produção. Antes do alojamento das aves, o galpão experimental passou por um vazio sanitário de 14 dias, sendo somente varrido, não foi utilizado lança chamas e nenhum produto desinfetante. Essas práticas foram adotadas com a intenção de simular condições semelhantes às encontradas em granjas comerciais, onde o desafio microbiano é normalmente maior do que em instalações experimentais. Acredita-se que os agentes antimicrobianos atuem com mais eficiência como promotores de crescimento em aves que estejam em situações de desafio microbiano.

Durante o vazio sanitário entre os lotes, o manejo adotado para a reutilização da cama do aviário foi o de amontoá-la no centro de cada box no primeiro dia e espalhá-la no $14^{\circ}$ dia. O material de cama da criação anterior consistiu de maravalha de madeira; formando uma camada de $7 \mathrm{~cm}$ de espessura; a cama foi revolvida a intervalos de 15 dias, conforme a necessidade; as placas úmidas que se formaram no interior dos boxes, principalmente ao redor dos bebedouros foram removidas e quantidades suficientes de maravalha eram repostas para manter a uniformidade da cama. 
No ciclo anterior foram utilizados 990 pintos distribuídos em 30 boxes e foram criados por 42 dias. O programa de promotores de crescimento e agentes coccidiostáticos usados foram idênticos para todos os boxes. Durante a condução deste ciclo não ocorreu nenhum problema sanitário e a mortalidade das aves foi de $1,2 \%$.

Análises microbiológicas da cama aviária foram feitas a fim de se obterem informações a respeito do grau de contaminação do galpão e se certificar da ocorrência de desafio microbiano. Foram realizadas duas coletas, uma no primeiro dia do experimento, antes do alojamento das aves e outra no último dia de criação.

A primeira coleta envolveu pequenas porções da cama que foram retiradas dos quatros cantos de cada box e em seguida o material dos 30 boxes foi homogeneizado no interior de um saco plástico e retirada uma única amostra, representando a cama do galpão experimental como um todo.

Para a coleta final foi adotado um procedimento semelhante ao descrito acima, com a diferença que as amostras foram coletadas por tratamentos. Desta forma cada amostra de um tratamento foi composta por sub-amostras de todas as suas repetições.

As amostras das duas coletas foram acondicionadas em sacos de papel e posteriormente conservadas em geladeira por um período máximo de 24 horas e enviadas ao laboratório de patologia em Campinas/SP.

No primeiro dia do experimento, logo após a chegada das aves foram observadas as condições físicas e de sanidade do lote. De forma geral as aves eram pequenas, com peso médio de $39 \mathrm{~g}$, provenientes de matrizes novas com aproximadamente 31 semanas de idade. As aves foram sexadas no momento do recebimento, com o intuito de conferir a sexagem feita no incubatório e observar melhor o estado geral da ave. Em seguida, as aves foram divididas em lotes de 40 pintos, pesadas e distribuídas nos 
30 boxes, de forma que o peso médio entre as unidades experimentais dentro de cada bloco fosse o mais homogêneo possivel.

Para a recepção das aves cada box foi equipado com um bebedouro infantil que foi abastecido com água pura e fresca poucas horas antes da chegada das aves. A partir do $3^{0}$ dia este bebedouro foi substituído pelo bebedouro tipo pendular. Ambos os bebedouros foram lavados 2 vezes ao dia. As rações iniciais foram fornecidas conforme os tratamentos em comedouros infantis com capacidade para $4 \mathrm{~kg}$. No $10^{0}$ dia os comedouros infantis foram trocados por comedouros tubulares com capacidade para 25 $\mathrm{kg}$ permanecendo até o término do experimento. Nas primeiras semanas foram utilizados círculos de folha de eucatex para conter as aves no centro dos boxes; sendo abertos gradualmente até serem retirados completamente na $2^{0}$ semana experimental. Foi utilizado jornal para revestir a cama no interior dos círculos por 3 dias.

Cada box continha um sistema de aquecimento por meio de lâmpada infravermelha de 250 watts, localizada na região central e suspensa a 0,50 $\mathrm{m}$ do piso. As lâmpadas foram acesas previamente ao alojamento das aves para que 0 ambiente atingisse uma temperatura ambiente de $33^{\circ} \mathrm{C}$, ideal para os primeiros dias de vida dos pintos. As lâmpadas de aquecimento foram mantidas acesas nos primeiros 7 dias e as cortinas de plástico nas laterais do galpão completamente fechada. Após esse período o manejo de aquecimento do galpão foi feito de acordo com a temperatura ambiente e o comportamento das aves. A partir da terceira semana experimental as lâmpadas de aquecimento foram totalmente retiradas $e$ as cortinas passaram a permanecer abertas durante o período diurno e noturno; sendo fechadas somente durante as chuvas.

A temperatura interna do galpão foi monitorada diariamente às 9:00 horas (Apêndice 7) através de dois termômetros de máxima e mínima, localizados nas fileiras laterais do galpão a $30 \mathrm{~cm}$ do piso. 
A iluminação artificial do galpão foi feita através de 7 lâmpadas incandescentes de 60 watts cada, dispostas na parte central a uma altura de $2,30 \mathrm{~m}$ do piso que permaneceram acesas por todo o periodo experimental.

As aves vieram vacinadas do incubatório contra as doenças de Marek, Gumboro e Bronquite Infecciosa. Aos 12 dias de vida as aves foram vacinadas contra as doenças de Newcastle e Gumboro. A vacina foi administrada via água de bebida, seguindo o procedimento: os bebedouros foram completamente esgotados e as aves permaneceram sem água por um período de 2 horas; em seguida as vacinas foram preparadas na diluição de 1.000 doses em 10 litros de água e distribuídas pelos bebedouros, logo depois foi feito um repasse, objetivando garantir o consumo por todas as aves.

Até $\circ 3^{0}$ dia do experimento as aves mortas ou refugadas foram trocadas por aves aparentemente sadias da mesma idade que estavam recebendo a dieta controle. A partir desta data sempre que era observado uma ave em condições deficientes esta era refugada com o objetivo de uniformizar o lote e evitar possivel discrepância na média do box.

\subsection{Tratamentos e Rações Experimentais}

Os tratamentos experimentais consistiram de uma ração basal (ração controle) não suplementada com qualquer microingrediente de alimentação promotor de crescimento e dessa mesma ração suplementada com diferentes promotores de crescimento, como detalhados a seguir: dois tratamentos foram formados pela ração basal suplementada com as fontes sulfato de cobre pentahidratado e citrato de cobre anidro; o outro foi adicionado à ração basal o antibiótico virginiamicina e o último tratamento foi a associação do antibiótico e citrato de cobre adicionados à ração basal. 


\section{TRATAMENTOS:}

- CONTROLE $\triangleright$ ração basal;

- SULFATO $\triangleright$ ração basal $+200 \mathrm{mg}$ cobre/kg (sulfato de cobre pentahidratado);

- CITRATO $\triangleright$ ração basal + $75 \mathrm{mg}$ cobre $/ \mathrm{kg}$ (citrato de cobre anidro);

- VM $\triangleright$ ração basal $+20 \mathrm{mg}$ virginiamicina $/ \mathrm{kg}$;

- CITRATO + VM $\triangleright$ ração basal $+75 \mathrm{mg}$ cobre $/ \mathrm{kg}$ (citrato de cobre anidro) $+20 \mathrm{mg}$ virginiamicina $/ \mathrm{kg}$.

As formas de cobre adicionadas às rações basais foram o sulfato de cobre pentahidratado, fórmula molecular $\mathrm{CuSO}_{4} \cdot 5 \mathrm{H}_{2} \mathrm{O}$, e o citrato de cobre anidro, fórmula molecular $\mathrm{C}_{6} \mathrm{H}_{4} \mathrm{CuO}_{7} \mathrm{O}$ citrato de cobre foi doado pela Griffin Corporation, localizada em Valdosta, Georgia, EUA. Foi realizado análise no laboratório de Controle de Qualidade da SUPREMAIS produtos Bioquímicos Ltda., localizado em Valinhos, São Paulo, constatando-se a presença de $37,38 \%$ de cobre no produto.

As rações basais foram divididas em três tipos conforme a fase de criação, sendo 1 a 21 dias (fase inicial), 22 a 35 dias (fase de crescimento) e 36 a 42 dias (fase final). Foram formuladas à base de milho e farelo de soja, usando-se a composição média desses ingredientes, para atender as exigências nutricionais recomendadas por Rostagno et al. (1983). Durante todo o período experimental a ração e água foram fornecidas ad libitum. A composição percentual das rações experimentais, bem como os nutrientes calculados estão apresentados na Tabela 2. 
Tabela 2- Composição percentual e valores calculados das rações basais

\begin{tabular}{|c|c|c|c|}
\hline Ingrediente \% & Inicial & Crescimento & Final \\
\hline Milho & 57,43 & 61,78 & 64,78 \\
\hline Farelo de Soja & 36,53 & 32,04 & 29,44 \\
\hline Óleo Vegetal & 2,26 & 2,04 & 2,40 \\
\hline Fosfato Bicálcico & 1,95 & 1,74 & 1,75 \\
\hline Calcário & 1,12 & 1,03 & 1,04 \\
\hline DL-Metionina 99 & 0,16 & 0,12 & 0,11 \\
\hline Sal & 0,30 & 0,30 & 0,30 \\
\hline Agente Anticoccidiano & 0,05 & 0,05 & - \\
\hline Cloreto de Colina & 0,05 & 0,05 & 0,05 \\
\hline Suplemento Vitamínico ${ }^{a}$ & 0,10 & 0,80 & 0,08 \\
\hline Suplemento Mineral $^{b}$ & 0,05 & 0,05 & 0,05 \\
\hline Total & 100,0 & 100,0 & 100,0 \\
\hline \multicolumn{4}{|c|}{ Valores Calculados } \\
\hline EM kcal/kg & $3.000^{-1}$ & $3.050^{-}$ & 3.050 \\
\hline Proteina Bruta \% & 21,64 & 20,00 & 19,00 \\
\hline Metionina \% & 0,49 & 0,44 & 0,41 \\
\hline Metionina + Cistina \% & 0,85 & 0,77 & 0,73 \\
\hline Lisina \% & 1,10 & 0,99 & 0,93 \\
\hline Cálcio \% & 1,00 & 0,90 & 0,90 \\
\hline Fósforo Disponível \% & 0,45 & 0,41 & 0,41 \\
\hline
\end{tabular}

${ }^{a}$ Cada kg do suplemento vitamínico contém: vit. A, $10.000 .000 \mathrm{Ul}$; vit. E, $12.500 \mathrm{mg}$; vit. K3, $2.500 \mathrm{mg}$; vit. B1, $6.000 \mathrm{mg}$; vit. B6, $3.200 \mathrm{mg}$; vit. B12, $12.000 \mathrm{mcg}$; ác. fólico, $1.000 \mathrm{mg}$; pantotenato de $\mathrm{Ca}, 12.500 \mathrm{mg}$ : niacina, $30.000 \mathrm{mg}$; antioxidante, $15 \mathrm{~g}$; Se, $200 \mathrm{mg}$.

bCada kg do suplemento mineral contém: $\mathrm{Mn}, 130.000 \mathrm{mg}$; $\mathrm{Cu}, 24.000 \mathrm{mg} ; \mathrm{Zn}, 100.000 \mathrm{mg}$; Fe, $80.000 \mathrm{mg} ; \mathrm{l}, 2.000 \mathrm{mg}$. 
As rações foram preparadas na fábrica de rações do Departamento de Produção Animal da ESALQ/USP. O procedimento adotado para a fabricação das rações foi o mesmo comumente usado em granjas comerciais. Primeiramente foi realizada uma pré-mistura em um misturador em " $Y$ " com capacidade para $30 \mathrm{~kg}$, com os seguintes ingredientes: fosfato bicálcico, calcário, DL-metionina, sal, agente anticoccidiano, cloreto de colina, suplemento vitamínico e mineral, inclusive os promotores de crescimento. Em seguida, num misturador vertical com capacidade para $500 \mathrm{~kg}$ foi misturada a metade da inclusão do milho e farelo de soja, adicionando aos poucos a prémistura. Depois acrescentou-se a outra metade do milho e farelo de soja e por último o óleo, permanecendo em mistura por 12 minutos.

\subsection{Variáveis Estudadas}

As aves foram pesadas semanalmente, sendo a primeira pesagem realizada no dia do recebimento das mesmas e a última pesagem realizada no $42^{\circ}$ dia do experimento. As variáveis estudadas foram peso vivo (PV), ganho de peso (GP), consumo de ração (CR), conversão alimentar (CA), mortalidade + refugagem (MR) e temperatura retal (TR).

O cálculo do peso vivo foi obtido através da divisão do peso de todas as aves do box pelo número de aves presentes na pesagem. $\mathrm{O}$ ganho de peso foi calculado pela diferença entre o peso vivo médio atual e o peso vivo médio da semana anterior. $O$ consumo de ração foi determinado dividindo-se a diferença entre a ração fornecida durante a semana e a sobra de ração pesada ao final da mesma pelo número de aves do box. Nos boxes em que houve mortalidade foi feita uma correção no consumo de ração de acordo com as seguintes fórmulas: 
CA ajustada $=\frac{\text { consumo de ração da semana }}{\left(\begin{array}{c}\text { peso total das } \\ \text { aves vivas }\end{array} \begin{array}{c}\text { peso total das } \\ \text { aves mortas }\end{array}\right)-\left(\begin{array}{c}\text { peso total das aves vivas } \\ \text { da semana anterior }\end{array}\right)}$

$C R$ médio ajustado $=C A$ ajustada individual $\times$ ganho de peso médio

A conversão alimentar foi calculada dividindo-se o consumo de ração médio pelo ganho de peso médio das aves do determinado box no período estudado. Nos casos em que ocorreu morte das aves a CA também foi ajustada considerando o peso das aves mortas.

O registro da mortalidade era feito no dia do evento, retirando-se a ave morta assim que encontrada e anotando-se o seu peso. A mortalidade + refugagem foi expressa em porcentagem nos períodos estudados.

A temperatura corporal foi medida na cloaca através de termômetro clínico digital (Omron®) cuja escala de medição é entre $32^{\circ} \mathrm{C}$ e $43^{\circ} \mathrm{C}$, com precisão de $\pm 0,1^{\circ} \mathrm{C}$ e mostrador com diferenciais de $0,01^{\circ} \mathrm{C}$. Foram amostradas 4 aves por box com peso vivo próximo ao peso médio do box. Essas medidas foram feitas semanalmente no período da tarde, logo após a pesagem das aves.

Deve-se ressaltar que todas as variáveis estudadas são médias, isto é, sempre o valor total da parcela experimental foi dividido pelo número de aves envolvidas na obtenção do determinado dado. 


\subsection{Análise Estatistica}

Para fins de análises estatísticas o período foi subdividido em outros três: 1 a 21 dias de idade; 22 a 42 dias de idade e 1 a 42 dias, correspondendo ao período total de criação.

As variáveis dependentes: $P V, G P, C R, C A, M R$ e TR foram submetidas à análise de variância, de acordo com o delineamento experimental utilizando os procedimentos do General Linear Models (GLM) do pacote computacional Statistical Analyses System (SAS) de análises estatísticas, as médias dos tratamentos foram comparadas pelo teste de Tukey a $5 \%$ de probabilidade.

O modelo matemático associado a esse delineamento foi:

$$
\begin{aligned}
& Y_{i j}=\mu+t_{i}+b_{j}+e_{i j} ; \\
& i=1,2,3,4,5 \quad \text { e } \quad j=1,2,3,4,5,6
\end{aligned}
$$

onde:

$$
\begin{aligned}
& Y_{i j}=\text { observação da variável do i-ésimo tratamento e do j-ésimo bloco; } \\
& \mu=\text { média geral; } \\
& t_{i}=\text { efeito do i-ésimo tratamento; } \\
& b_{j}=\text { efeito do j-ésimo bloco; } \\
& e_{i j}=\text { efeito residual devido ao erro aleatório. }
\end{aligned}
$$


O esquema da análise de variância foi o seguinte:

Tabela 3. Esquema da análise de variância (ANOVA)

\begin{tabular}{lc}
\hline Causas de Variação & Graus de Liberdade \\
\hline Dietas & 4 \\
Bloco & 5 \\
Resíduo & 19 \\
\hline Total & $\mathbf{2 0}$ \\
\hline
\end{tabular}




\section{RESULTADOS E DISCUSSÃO}

Os dados coletados durante o periodo experimental do desempenho e da temperatura retal das aves que receberam as dietas experimentais contendo os diferentes agentes antimicrobianos estão apresentados nos Apêndices 1 a 6 .

\subsection{DESEMPENHO DOS FRANGOS DE CORTE DE 1 A 21 DIAS DE IDADE}

$\mathrm{Na}$ Tabela 4 estão apresentados os resultados médios de peso vivo (PV), ganho de peso (GP), consumo de ração (CR), conversão alimentar (CA) e mortalidade + refugagem (MR) dos frangos de corte na fase inicial (1 a 21 dias) de criação das aves.

Não se observou diferença significativa $(P>0,05)$ entre os tratamentos em nenhuma variável estudada na fase inicial de criação dos frangos de corte, indicando que o uso dos promotores de crescimento estudados não afetou o desempenho das aves. Estes resultados não estão de acordo com os encontrados na literatura (March et al., 1978; Stutz e Lawton, 1984; Zuanon et al., 1998) que apontam um maior estímulo no crescimento com o uso de agentes antimicrobianos como promotores de crescimento na fase inicial de criação das aves. 
Tabela 4. Peso vivo, ganho de peso, consumo de ração, conversão alimentar e mortalidade + refugagem dos frangos de corte alimentados com rações contendo diferentes microingredientes de alimentação, na fase inicial (1 a 21 dias).

\begin{tabular}{lccccc}
\hline \multicolumn{1}{c}{ Tratamento } & \multicolumn{5}{c}{ Variáveis } \\
\cline { 2 - 6 } & PV $(\mathrm{kg})$ & GP $(\mathrm{kg})$ & CR $(\mathrm{kg})$ & CA & MR $(\%)$ \\
\hline CONTROLE & 0,755 & 0,715 & 1,256 & 1,757 & 0,83 \\
SULFATO & 0,745 & 0,705 & 1,271 & 1,805 & 1,25 \\
CITRATO & 0,747 & 0,707 & 1,300 & 1,840 & 0,42 \\
VM & 0,758 & 0,719 & 1,258 & 1,752 & 0,83 \\
CITRATO + VM & 0,765 & 0,724 & 1,267 & 1,750 & 0,42 \\
\hline${ }^{1}$ C.V. $(\%)$ & 2,50 & 2,63 & 3,24 & 4,71 & 209,9 \\
\hline
\end{tabular}

${ }^{1}$ Coeficiente de variação

Considerando a fase de 1 a 21 dias observa-se que o GP das aves que receberam os tratamentos VM e CITRATO + VM foram semelhantes ao CONTROLE. Mesmo não sendo estatisticamente significativo $(P>0,05)$, o GP das aves alimentadas com as fontes de $\mathrm{Cu}$ isoladas foi cerca de $1,3 \%$ inferior ao CONTROLE. A suplementação com os promotores de crescimento nas dietas dos frangos de corte proporcionou um aumento no CR quando comparados ao CONTROLE, sendo que as aves que receberam os tratamentos SULFATO e CITRATO apresentaram os maiores consumos em comparação ao CONTROLE (1,19 e 3,5\%, respectivamente). Foi demonstrado que o cobre estimula o consumo de ração em suínos (Zhou et al. 1994a; Dove, 1995). O aumento no CR das aves dos tratamentos SULFATO e CITRATO não foi acompanhado de maior ganho de peso, resultando em pioras não significativas $(P>0,05)$ na $C A$, da ordem de 2,73 e 4,72 \%, respectivamente. Em relação a MR foi observada uma maior proporção no tratamento SULFATO, embora não diferente estatisticamente. 
Animais jovens apresentam um marcante aumento e mais consistente resposta aos antibióticos quando comparados com animais mais velhos. Hawbaker et al. (1960) testaram niveis crescentes de oleandomicina em dois grupos de suínos, com idade inicial de 13 e 51 dias. Nos suínos mais novos, o resultado foi um aumento na taxa de crescimento variando de $30 \%$ a $44 \%$ e uma melhora na eficiência alimentar entre $14 \%$ e $20 \%$; em suínos mais velhos o resultado foi uma melhora de $7 \%$ a $10 \%$ na taxa de crescimento e eficiência alimentar.

Fernandez et al. (1973) concluíram que o estímulo ao crescimento com o uso de agentes antimicrobianos ocorre durante as quatro primeiras semanas de idade dos frangos de corte. Após essa idade as diferenças no ganho de peso das aves desaparecem.

Ariki et al. (1977), adicionando bacitracina de zinco em rações à base de sorgo para frangos de corte, verificaram que na fase inicial do crescimento dos pintos a adição de bacitracina resultou em melhora significativa na conversão alimentar $(10 \%)$ e para o ganho de peso não houve diferença entre os tratamentos. A melhor conversão alimentar foi devida ao menor consumo (7\%) das aves que receberam a bacitracina. Entretanto a adição do antibiótico da $5^{\circ}$ a $9^{\circ}$ semana de idade não trouxe efeito significativo no desempenho das aves.

Em contrapartida, Junqueira et al. (1992) avaliaram o uso de dois niveis de cloridrato de clorhexidina (10 e 20 ppm) e observaram que na fase inicial (1 a 21 dias) o promotor de crescimento não proporcionou melhora no desempenho de frangos de corte quando comparado com a testemunha.

Pesti \& Bakalli (1996), estudando o efeito da suplementação com 250 ppm de cobre na forma de sulfato de $\mathrm{Cu}$, não observaram efeito do mineral sobre o ganho de peso e conversão alimentar dos frangos de corte no período de 1 a 21 dias. Estes resultados concordam com o presente trabalho em que não houve diferença estatística no desempenho dos frangos de corte na fase inicial com a utilização do sulfato de $\mathrm{Cu}$. 
Ewing et al. (1998) realizaram dois experimentos para testar três fontes distintas de $\mathrm{Cu}$ (sulfato, oxicloreto e citrato) na dosagem de $125 \mathrm{ppm}$ cada em rações para frangos de corte; em um dos experimentos foi também testado 0 citrato de cobre ao nível de $63 \mathrm{ppm}$ de $\mathrm{Cu}$. Em ambos os experimentos não houve diferença significativa dos tratamentos estudados sobre o peso vivo e conversão alimentar com a suplementação de Cu até os 21 dias de idade dos frangos de corte.

\subsection{DESEMPENHO DOS FRANGOS DE CORTE DE 22 A 42 DIAS DE IDADE}

A Tabela 5 apresenta os resultados médios de desempenho dos frangos de corte referentes ao periodo de 22 a 42 dias de criação das aves, correspondendo à fase final. $\mathrm{O} G P$ e $C R$ não diferiram estatisticamente $(P>0,05)$ entre os tratamentos estudados. Foi observada diferença significativa $(P<0,05)$ nas variáveis $C A$ e $M R$.

Tabela 5. Ganho de peso, consumo de ração, conversão alimentar e mortalidade + refugagem dos frangos de corte alimentados com rações contendo diferentes microingredientes de alimentação, na fase final (22 a 42 dias).

\begin{tabular}{lcccc}
\hline \multirow{2}{*}{ Tratamento } & \multicolumn{4}{c}{ Variáveis } \\
\cline { 2 - 5 } & $\mathrm{GP}(\mathrm{kg})$ & $\mathrm{CR}(\mathrm{kg})$ & $\mathrm{CA}$ & $\mathrm{MR}(\%)$ \\
\hline CONTROLE & 1,611 & 3,296 & $2,046^{\mathrm{a}}$ & $2,92^{\mathrm{ab}}$ \\
SULFATO & 1,631 & 3,288 & $2,015^{\mathrm{ab}}$ & $5,00^{\mathrm{a}}$ \\
CITRATO & 1,626 & 3,250 & $2,000^{\mathrm{ab}}$ & $0,83^{\mathrm{b}}$ \\
VM & 1,616 & 3,217 & $1,991^{\mathrm{b}}$ & $1,25^{\mathrm{b}}$ \\
CITRATO + VM & 1,594 & 3,242 & $2,034^{\mathrm{ab}}$ & $1,25^{\mathrm{b}}$ \\
\hline${ }^{1}$ C.V. (\%) & 1,91 & 1,48 & 1,51 & 80,38
\end{tabular}

\footnotetext{
${ }^{1}$ Coeficiente de variação

a,b Médias seguidas de letras diferentes na coluna diferem entre si pelo teste de Tukey $(P<0,05)$
} 
Pode-se observar que as médias para o GP foram numericamente maiores para o SULFATO e CITRATO quando comparadas com os outros tratamentos. O CR foi cerca de $1,4 \%$ maior para as aves que receberam a dieta CONTROLE, diferindo da fase inicial em que esse tratamento proporcionou o menor consumo quando comparado com os demais, contudo devemos lembrar que não foi detectada diferença estatística nessa variável.

Comparados aos frangos não suplementados (CONTROLE), os que receberam 0 antibiótico VM tiveram a CA melhorada significativamente $(P<0,05)$ na fase final, com uma vantagem de $2,7 \%$ nos valores da $C A$. Tanto $o$ CONTROLE como a VM não diferiram dos demais tratamentos. A MR foi diferente significativamente $(P<0,05)$; o SULFATO resultou em maior MR $(5,0 \%)$ das aves quando comparado com o CITRATO, VM e CITRATO + VM $(0,83 ; 1,25$ e $1,25 \%$, respectivamente) porém não diferiu do CONTROLE $(2,92 \%)$. O CONTROLE por sua vez não diferiu dos demais tratamentos $(\mathrm{P}>0,05)$.

\subsection{DESEMPENHO DOS FRANGOS DE CORTE DE 1 A 42 DIAS DE IDADE}

$\mathrm{Na}$ Tabela 6 estão apresentados os resultados médios obtidos em PV, GP, CR, CA e MR de frangos de corte submetidos aos diferentes promotores de crescimento no período total de criação que foi de 1 a 42 dias. Não houve diferença estatisticamente significativa $(P>0,05)$ entre tratamentos nas médias das variáveis de desempenho estudadas quando foi avaliado o período total do experimento; apenas a MR foi afetada, sendo que o SULFATO ocasionou. maior mortalidade e refugagem das aves quando comparado com os tratamentos CITRATO, VM e CITRATO + VM $(P<0,05)$. O SULFATO não diferiu estatisticamente do CONTROLE $(P>0,05)$, porém a MR das aves que receberam o tratamento SULFATO foi numericamente maior. 
Tabela 6. Peso vivo, ganho de peso, consumo de ração, conversão alimentar e mortalidade + refugagem dos frangos de corte alimentados com rações contendo diferentes microingredientes de alimentação, no período total de criação das aves (1 a 42 dias).

\begin{tabular}{|c|c|c|c|c|c|}
\hline \multirow[t]{2}{*}{ Tratamento } & \multicolumn{5}{|c|}{ Variáveis } \\
\hline & PV (kg) & GP (kg) & $\overline{\mathrm{CR}(\mathrm{kg})}$ & $\overline{\mathrm{CA}}$ & MR (\%) \\
\hline CONTROLE & 2,366 & 2,326 & 4,551 & 1,957 & $3,75^{\mathrm{ab}}$ \\
\hline SULFATO & 2,376 & 2,336 & 4,560 & 1,952 & $6,25^{a}$ \\
\hline CITRATO & 2,372 & 2,333 & 4,550 & 1,951 & $1,25^{b}$ \\
\hline VM & 2,374 & 2,335 & 4,476 & 1,917 & $2,08^{b}$ \\
\hline CITRATO+ VM & 2,359 & 2,319 & 4,510 & 1,945 & $1,67^{b}$ \\
\hline${ }^{1}$ C.V. (\%) & 1,56 & 1,58 & 1,38 & 1,76 & 70,38 \\
\hline
\end{tabular}

Com relação ao PV aos 42 dias de idade, as aves de todos os tratamentos apresentaram um peso corporal muito próximo entre si. A ausência de resposta aos promotores de crescimento usados neste experimento talvez possa ser justificada pelo grande potencial genético para ganho de peso da linhagem utilizada. Pode-se observar que as aves CONTROLE, mesmo sem suplementação de qualquer promotor, obtiveram um bom desempenho com peso vivo médio de $2,366 \mathrm{~kg}$ vs 2,$376 ; 2,372 ; 2,374 ; 2,359 \mathrm{~kg}$ para SULFATO,CITRATO, VM e CITRATO + VM, respectivamente.

Um outro fator a ser considerado se refere às condições sanitárias em que as aves foram submetidas. Frangos alojados em galpões limpos, desinfetados crescem mais rápido e mais eficientemente do que aqueles frangos alojados em condições de baixa sanidade, ainda que na ausência de sinais clínicos de doenças infecciosas (Hill et al., 1952). Os animais de forma geral estão sempre com o sistema imunológico ativo, principalmente quando estão sob condições 
sanitárias precárias, por exemplo, instalações sujas, altas concentrações de microrganismos no ambiente, etc; estas condições de ativação do sistema imunológico e as alterações metabólicas específicas que ocorrem, são determinadas de "estresse imunológico" (Klasing et al., 1987). O estresse imunológico leva a uma série de eventos que pode redirecionar os nutrientes para atender às necessidades energéticas da resposta imune, em vez de crescimento muscular, deprimindo assim o crescimento (Ferket, 1999).

Cromwell (1991) relatou que uma evidência adicional para suportar a hipótese do efeito no controle de doenças proporcionado pelos agentes antimicrobianos seria que o grau de resposta desses compostos é fortemente influenciada pela higiene do ambiente e a carga de doença que o animal esta envolvido.

As respostas aos antibióticos geralmente são minimizadas quando testados em ambiente limpo e com menos estresse. Hays \& Speer (1960) mostraram que os antibióticos são mais efetivos em leitões criados em creches com instalações mais sujas quando comparadas às limpas. Os autores testaram os antibióticos espiramicina, clortetraciclina e oxitetraciclina em ambientes limpos e sujos e verificaram que os leitões recebendo os antibióticos tiveram uma melhora no ganho de peso de $28 \%$ e $55 \%$, quando criados em ambiente limpo e sujo, respectivamente. A conversão alimentar também foi melhorada em $8 \%$ e $29 \%$ em ambientes limpo e sujo, respectivamente. Segundo Cromwell (1991) esta maior resposta dos antibióticos em ambiente sujo é atribuída ao fato desses microingredientes suprimirem as bactérias que são responsáveis pela redução no desempenho devido às doenças subclínicas.

O cobre também possui esta propriedade antimicrobiana (Shurson et al., 1990; Menten, 1995). Em recentes experimentos realizados na Esalq/USP com frangos de corte (Brainer, 1998; Morais, 1999) e com suínos (Lima, 1999) foram testados a eficiência do citrato cúprico e do sulfato cúprico como promotores de crescimento. As autoras verificaram que o cobre não foi eficiente em promover 
o crescimento dos animais e justificaram a ausência de resposta às excelentes condições sanitárias dos animais e das instalações experimentais.

No presente trabalho a cama de frango foi reutilizada com o intuito de induzir desafio microbiano. Atualmente devido a razões econômicas e/ou ecológicas a grande maioria dos produtores passou a utilizar a mesma cama para lotes consecutivos de frangos de corte. Entretanto há dúvidas quanto à possibilidade de veicular agentes patogênicos para os lotes subsequentes. Certamente esta possibilidade existe, mas através de métodos relativamente simples esse problema pode ser amenizado. Há fortes indícios que a tentativa de simular uma condição de campo através da reutilização da cama no presente estudo não foi suficiente para aumentar a carga patogênica e consequentemente estimular a ação dos agentes antimicrobianos testados.

Observando-se os resultados da análise microbiológica da cama Tabela 7 pode-se verificar que a contagem de coliformes totais e fecais na primeira amostra, foi baixa e a pesquisa para oocisto foi negativa. Provavelmente a prática de amontoar as camas durante o vazio sanitário promoveu um processo fermentativo propiciando uma cama com baixa contagem de bactérias patogênicas.

Paganini (2000) confirmou a eficiência do processo de fermentação na diminuição da carga bacteriana da cama de frangos de corte. $O$ experimento foi desenvolvido numa grande integração avícola do Sul do pais; mediu-se a contaminação de amostras de maravalhas coletadas no dia da saída do lote (Cl). Em seguida a cama foi amontoada em duas leiras longitudinais não cobertas (LL) ou em uma leira longitudinal coberta com lona preta (LC). Após sete dias, foram novamente determinadas as contagens bacterianas dessas camas. Como controle foi amostrado material no depósito da propriedade (CO). Os resultados indicaram que o processo de fermentação foi efetivo em diminuir a contaminação bacteriana. A contagem de coliformes totais (unidades formadoras de colônia/grama) para CI, LL, LC e CO foi 65620, 1670, 100 e 5964, respectivamente. Para coliformes fecais (unidades formadoras de 
colônia/grama) para Cl, LL, LC e CO foi 49400, 450, 100 e 4090, respectivamente.

A ausência de oocisto na cama nos indica que possivelmente não houve um desafio por eimeria, fato este reforçado pela sintomatologia negativa para coccidiose apresentada pelas aves.

Os valores da segunda amostra da cama foram menores em termos absolutos em relação a primeira amostra, estando aquém de caracterizar uma contaminação severa quer por eimeira ou por coliformes que poderia levar as aves a uma condição de estresse imunológico.

Tabela 7. Análise microbiológica da cama do galpão experimental

\begin{tabular}{|c|c|c|c|c|}
\hline Tipo de Cama & $\begin{array}{c}\text { Coliforme } \\
\text { total } \\
\text { (col/gr) }\end{array}$ & $\begin{array}{c}\text { Coliforme } \\
\text { fecal } \\
\text { (col/gr) }\end{array}$ & $\begin{array}{l}\text { Presença } \\
\text { Oocistos }\end{array}$ & $\begin{array}{c}\text { Isolamento } \\
\text { Escherichia } \\
\text { coli }\end{array}$ \\
\hline Primeira amostra & 1100 & 43 & negativo & - \\
\hline đ CONTROLE & 460 & 11 & negativo & positivo \\
\hline SULFATO & 210 & 6,1 & negativo & positivo \\
\hline 胥 CITRATO & 460 & 7,2 & negativo & positivo \\
\hline$\stackrel{ }{5}$ VM & 1100 & 11 & negativo & positivo \\
\hline 总 CITRATO+ VM & 210 & 6,1 & negativo & positivo \\
\hline
\end{tabular}

A baixa mortalidade das aves criadas anteriormente $(1,2 \%)$, juntamente com a baixa densidade de lotação $\left(6,6\right.$ aves $\left./ \mathrm{m}^{2}\right)$, bons índices zootécnicos e um vazio sanitário de 14 dias entre os lotes também são fatores que podem caracterizar um baixo desafio microbiano.

A associação entre uma nutrição balanceada, a utilização de animais com um material genético selecionado para alto ganho de peso e instalações em condições sanitárias apropriadas proporcionou um excelente desempenho das 
aves e com isso os microingredientes usados não conseguiram expressar a sua ação promotora do crescimento.

Como foi citado anteriormente o estresse imunológico é um termo usado para descrever algum tipo de exposição a antígeno sofrido pela ave, resulta em alterações metabólicas que modulam a resposta imune. Uma ave que sofreu um desafio imunológico, por exemplo, produz diversas citoquinas, como Interleucina - 1 (IL - 1) que podem aumentar a taxa metabólica, diminuir o apetite e induzir uma resposta febril (Klasing et al., 1987; Ferket, 1999).

Kent et $\mathrm{al}^{5}$., citados por Kelley et al. (1993), demonstraram que a IL -1 , injetada intraperitonialmente (ip), aumenta o consumo de oxigênio, a temperatura corporal, reduz o consumo alimentar e o interesse pelas atividades sociais. Estes resultados confirmam que a IL -1 é um potente indutor de febre e anorexia, reconhecida como mediadora das mudanças imunológicas. A febre é considerada o primeiro sinal de manifestação da resposta imune, definida como um aumento na temperatura corporal (Kelley et al., 1993).

Klasing et al. (1987) correlacionaram o aumento de temperatura corporal com o aumento da IL -1 em aves. Foi demonstrado que as injeções ip de IL 1 e lipopolissacarideo (LPS - Escherichia coli) induziram o aumento da temperatura corporal em frangos de corte $\left(42,5\right.$ e $42,3^{\circ} \mathrm{C}$, respectivamente) quando comparados com o controle, solução salina $\left(41,5^{\circ} \mathrm{C}\right)$.

Um dos modos de ação dos agentes antimicrobianos como promotores de crescimento bastante aceito entre os pesquisadores, se refere a sua ação na microflora intestinal patogênica, diminuindo assim a necessidade de ativação do sistema imune do animal.

Em animais tratados com antibióticos promotores de crescimento esperase que a produção de anticorpos seja menor em comparação àqueles que não recebem, consequentemente a quantidade de IL - 1 para mediar o sistema

${ }^{5}$ Kent, S., Bluthé, R.M., Dantzer, R., Hardwick, A.J., Kelley, K.W. Rothwell, N.J., Vannice, J.L. (1992) Different receptor mechanisms mediate the pyrogenic and behavioral effects of interleukin-1. Proceeding of the National Academy of Sciences of the USA 89, 9117-9120. 
imunológico também é menor e a temperatura corporal se mantêm em homeostase.

Observando a Tabela 8 verifica-se que a temperatura retal dos frangos não foi diferente estatisticamente ao longo do período estudado; apenas aos 28 dias foi observado uma diminuição $\left(0,29^{\circ} \mathrm{C}\right)$ na temperatura das aves que receberam CITRATO + VM quando comparadas ao CONTROLE e VM $(P<0,05)$, entretanto não diferindo dos demais tratamentos. Por sua vez 0 CONTROLE e VM não foi diferente estatisticamente do SULFATO e CITRATO.

Estes resultados são conflitantes quando comparados com os dados de desempenho dessas aves, pois o aumento de temperatura corporal esta correlacionado com diminuição no consumo de ração e consequentemente uma possivel piora no desempenho, fato este não confirmado no presente experimento (Tabelas 4, 5 e 6 ). Assim, pode-se considerar que as diferenças significativas nesta variável foi devido a um efeito casual.

Roura et al. (1992) estudaram o efeito do uso de antibiótico como promotor de crescimento e a relação com a atividade do sistema imunológico. No experimento 1, frangos de corte foram alimentados com dois níveis de antibióticos (0 e $200 \mathrm{mg} / \mathrm{kg}$ de uma mistura 1:1 de penicilina e estreptomicina), alojados em dois ambientes, um limpo e outro sujo. Os frangos criados em ambiente sujo e sem antibiótico tiveram um menor ganho de peso e piora na eficiência alimentar $(P<0,05)$ e maiores concentrações de IL-1 no plasma sanguíneo quando comparados com frangos criados em ambiente limpo ou sujo suplementados com antibiótico. Em frangos criados em ambiente limpo, o uso de antibióticos não afetou as concentrações de IL-1. No experimento 2 , os autores forneceram dietas com ou sem $100 \mathrm{mg} / \mathrm{kg}$ de tetraciclina para frangos de corte. Depois de 15 dias, a metade dos frangos foi injetado ip com LPS de Salmonella thiphimurium (100 mg/L) e mediram a temperatura cloacal. Verificaram aumento de $0,30^{\circ} \mathrm{C}$ na temperatura retal dos frangos que receberam a injeção quando comparados com aqueles que não receberam. Semelhantemente, os frangos que não foram alimentados com dietas com 
antibióticos também tiveram maiores temperaturas $\left(0,23^{\circ} \mathrm{C}\right)$ do que aves que receberam antibiótico na ração. Os frangos alimentados com antibiótico apresentaram melhor eficiência alimentar, maior ganho de peso e consumo de ração.

Tabela 8. Temperatura retal média dos frangos de corte alimentados com rações contendo diferentes microingredientes de alimentação. Período experimental de 7 a 42 dias.

\begin{tabular}{lcccccc}
\hline \multirow{1}{*}{ Tratamento } & \multicolumn{6}{c}{ Temperatura retal $\left({ }^{\circ} \mathrm{C}\right)$} \\
\cline { 2 - 7 } & \multicolumn{7}{c}{ Dias } \\
\cline { 2 - 7 } & $\mathbf{7}$ & 14 & 21 & 28 & 35 & 42 \\
\hline CONTROLE & 41,31 & 41,70 & 41,80 & $41,93^{\mathrm{a}}$ & 41,98 & 42,10 \\
SULFATO & 41,21 & 41,69 & 41,67 & $41,89^{\mathrm{ab}}$ & 41,97 & 41,96 \\
CITRATO & 41,23 & 41,75 & 41,71 & $41,78^{\mathrm{ab}}$ & 42,05 & 41,85 \\
VM & 41,17 & 41,82 & 41,93 & $41,95^{\mathrm{a}}$ & 41,97 & 41,91 \\
CITRATO + VM & 41,22 & 41,68 & 41,80 & $41,65^{\mathrm{b}}$ & 41,91 & 41,88 \\
Média & $\mathbf{4 1 , 2 3}$ & $\mathbf{4 1 , 7 3}$ & $\mathbf{4 1 , 7 8}$ & $\mathbf{4 1 , 8 4}$ & $\mathbf{4 1 , 9 8}$ & $\mathbf{4 1 , 9 5}$ \\
\hline${ }^{1}$ C.V. (\%) & 0,53 & 0,29 & 0,68 & 0,37 & 0,44 & 0,50 \\
\hline
\end{tabular}

${ }^{1}$ Coeficiente de variação

a,b Médias seguidas de letras diferentes na coluna diferem entre si pelo teste de Tukey $(P<0,05)$

A MR do grupo de aves que recebeu a dieta sulfato foi maior em todos os periodos estudados; pode-se observar que houve um aumento com o decorrer do experimento o que nos leva a assumir a hipótese de uma possivel toxicidade ao cobre. Entretanto, os dados de mortalidade deste experimento discordam de vários trabalhos citados na literatura, relatando que niveis abaixo de $250 \mathrm{ppm}$ de $\mathrm{Cu}$ na forma de sulfato de $\mathrm{Cu}$ não resulta em toxicidade e consequentemente em alta mortalidade.

Milles et al. (1998), testando sulfato de Cu e cloreto de cobre tribásico (0, 200, 400 e 600 ppm de Cu/kg de ração), não observaram efeito dos 
tratamentos sobre a mortalidade dos frangos, diferindo do presente trabalho que em níveis de $200 \mathrm{ppm}$ de Cu/kg de ração aumentou significativamente a mortalidade quando comparada com os demais tratamentos. O peso vivo e conversão alimentar das aves suplementadas com até $400 \mathrm{ppm}$ de $\mathrm{Cu}$, independente da fonte, não foi diferente estatisticamente.

Funk \& Baker (1991), testando níveis de Cu $(100,200,400$ ou $800 \mathrm{mg}$ de $\mathrm{Cu} / \mathrm{kg}$ de ração) na forma de sulfato de $\mathrm{Cu}$ verificaram que os sinais de toxicidade apresentados pelas aves dependem da dieta que está sendo fornecida; a adição de $800 \mathrm{mg}$ de Cu/kg de ração em dietas semipurificadas à base de caseína diminuiu o ganho de peso cerca de $63 \%$, mas a mesma adição de Cu para a dieta à base de milho e farelo de soja diminuiu o ganho de peso somente em $8 \%$.

Ewing et al. (1998) observaram que numericamente a mortalidade dos frangos de corte foi maior quando se usou $125 \mathrm{ppm}$ de $\mathrm{Cu}$ na forma de sulfato (10\%) quando comparada as fontes oxicloreto $(6,1 \%)$ e citrato de cobre $(7,8 \%)$, nos mesmos níveis.

Considerando o período total do experimento, as análises estatísticas indicaram que não houve efeito significativo do tratamento CITRATO + VM sobre as variáveis de desempenho estudadas, em comparação aos tratamentos CITRATO e VM isolados, o que indica não haver efeito aditivo ou sinérgico entre estes promotores de crescimento.

$\mathrm{Na}$ literatura encontramos diversos resultados indicando efeito sinérgico entre antibiótico e cobre em rações de suínos (Stahly et al., 1980; Coffey et al., 1994; Menten, 1995). Cromwell (1991), analisando dados de 14 experimentos envolvendo 1.700 suínos (7 a $18 \mathrm{~kg}$ ), verificou que o uso combinado de antibiótico e cobre proporcionou uma melhora no ganho de peso e na conversão alimentar em comparação a esses promotores de crescimento usados isoladamente. 


\section{CONCLUSÕES}

Analisando os resultados obtidos neste trabalho, pode-se concluir que:

- Considerando o período total de criação dos frangos de corte (1 a 42 dias de idade) os promotores de crescimento testados (sulfato de cobre, citrato de cobre e virginiamicina) não influenciaram o desempenho das aves.

- O citrato de cobre anidro não se revelou mais eficiente que o sulfato de cobre pentahidratado como promotores de crescimento.

- Não foi observado efeito sinérgico entre o citrato de cobre e a virginiamicina sobre nenhuma variável estudada.

- Aparentemente não se conseguiu aumentar o desafio microbiano no galpão experimental através do uso de cama reutilizada.

- Nas condições em que o experimento foi conduzido, os resultados sugerem que o uso de antibióticos ou altas doses de cobre podem ser evitados. Entretanto deve-se estar ciente que muitas vezes as condições sanitárias e de manejo observadas em campo não são as mesmas das condições experimentais.

- De forma geral os promotores de crescimento usados não proporcionaram redução na temperatura corporal das aves.

- Com base nos dados de desempenho e temperatura retal das aves não foi possivel correlacionar as variáveis estudadas com a ativação do sistema imunológico. 


\section{REFERÊNCIAS BIBLIOGRÁFICAS}

ANDRIGUETTO, J.M.; PERLY, L.; MINARDI, I.; GEMAEL, A.; FLEMMING, J. S.; SOUZA, G.A.; BONA FILHO, A. Nutrição animal. 4.ed. São Paulo: Nobel, 1991. v. 1, 395p.

APGAR, G.A.; KORNEGAY, E.T. Mineral balance of finishing pigs fed copper sulfate or a copper-lysine complex at growth-stimulating levels. Journal of Animal Science, v.74, p.1594-1600, 1996.

APGAR, G.A.; KORNEGAY, E.T.; LINDERMANN, M.D.; NOTTER, D.R. Evalution of copper sulfate and a copper lysine complex as growth promoters for weanling swine. Journal of Animal Science, v.73, p.26402646, 1995.

ARIKI, J.; KRONKA, R.N.; COSENZA, G.W. Antibióticos em rações a base de sorgo para frangos de corte. Científica, v.5, n.2, p.209-212, 1977

AZEVEDO, J.L. Genética de microorganismos em biotecnologia e engenharia genética. Piracicaba: Fealq, 1985. 173 p.

BAKALLI, R.I.; PESTI, G.M. RAGLAND, W.L.; KONJUFCA, V. Dietary copper in excess of nutritional requeriment reduces plasma and breast muscle cholesterol of chickens. Poultry Science, v.74, p.360-365, 1995. 
BAKER, D.H.; ODLE, J.; FUNK, M.A.; WIELAND, T.M. Research note: bioavailability of copper in cupric oxide, cuprous oxide, and in a copperlysine complex. Poultry Science, v.70, p.177-179, 1991.

BENICIO, L.A.S. Painel: restrições e uso de aditivos (promotores de crescimento) em rações de aves; visão da indústria. In: CONFERÊNCIA APINCO DE CIÊNCIA E TECNOLOGIA AVÍCOLAS, Curitiba, 1996 Anais. Local: FACTA, 1996. p.17-26.

BERTECHINI, A.G. Fisiologia da digestão de suínos e aves. Lavras: Fundação de Apoio ao Ensino, Pesquisa e Extensão, 1994, p.141.

BERTECHINI, A.G.; HOSSAIN, S.M. Efeito da utilização de probiótico sobre o desempenho de frangos de corte. In: BIOTECNAL. O fantástico mundo dos probióticos. Três Corações, 1992. p.65-68.

BIRD, H.R. Effectiveness of antibiotics in broiler feeds. Worl'ds Poultry Science Journal, v.24, n.4, p.309-312, 1968.

BRAINER, M.M.A. Efeitos de Citrato Cúprico em diferentes fases de criação como promotores de crescimento de frangos de corte. Piracicaba, 1998. 81p. Dissertação (Mestrado) - Escola Superior de Agricultura "Luiz de Queiroz", Universidade de São Paulo.

BURESH, R.E.; MILES, R.D.; HARMS, R.H. Influence of Virginiamycin on phosphorus utilization by broiler chicks. Poultry Science, v.64, p.757-758, 1985. 
BUTOLO, J.E. Agentes antimicrobianos em rações de aves e suínos. In: 35., REUNIÃO ANUAL DA SOCIEDADE BRASILEIRA DE ZOOTECNIA, Botucatu, 1998. Anais. Botucatu: UNESP, FMVZ, 1998. p.237 -254.

COFFEY, R.D.; CROMWELL, G.L.; MONEGUE, H.J. Efficacy of a copperlysine complex as a growth promotant for weanling pigs. Journal of Animal Science, v.72, p.2880-2886, 1994.

COMPÊNDIO brasileiro de alimentação animal. Brasília: Ministério de Agricultura, 1998. $1 \mathrm{v}$.

COOK, R.H.; BIRD, F.H. Duodenal villus area and epithelial cellular migration in conventional and germ-free chicks. Poultry Science, v.52, p.2276-2280, 1973.

COUTINHO, R. Noções de fisiologia da nutrição. 2. ed. Rio de Janeiro Editora Cultura Médica, 1981 p.241-247: Cobre.

CROMWELL, G.L. Agents antimicrobial. In: MILLER, E.R.; ULREY, D.E.; LEWIS, A.J. Swine nutriton. Stoneham: Butterworth-Heinemann, 1991. p.297-314.

CROMWELL, G.L.; LINDEMANN, M.D.; MONEGUE, H.J.; HALL, D.D.; ORR JÚNIOR, D.E. Tribasic copper choride and copper sulfate as copper sources for weanling pigs. Journal of Animal Science, v.76, p.118-123, 1998.

DOVE, C.R. The effect of copper level on nutrient utilization of weanling pigs. Journal of Animal Science, v.73, p.166-171, 1995. 
DUKES, H.H. Fisiologia dos animais domésticos. 11.ed. Rio de Janeiro: Guanabara, 1993.

ERPELDING, D.L. Promotores de crescimento: ciência vs política. In: SIMPÓSIO INTERNACIONAL SOBRE NUTRIÇÃO DE AVES, Campinas, 1999. Anais. FACTA, 1999. p.187-197.

EWING, H.P.; PESTI, G.M.; BAKALLI, R.I.; MENTEN, J.F.M. Studies on the feeding of cupric sulfate pentahydrate, cupric citrate, and copper oxycloride to broiler chickens. Poultry Science, v.77, p.445-448, 1998.

FEIGHNER, S.D.; DASHKEVICZ, M.P. Subtherapeutic levels of antibiotics in poutry feeds and their effects on weight gain, feed efficiency, and bacterial cholyltaurine hidrolase activity. Applied and Environmental Microbiology, v.53, n.2, p.331-336, 1987.

FERKET, P.R. Fatores que afetam a resposta imunológica: nutrição. In: Congresso de produção e consumo de ovos. São Paulo, 1999. Anais. São Paulo: APA (Associação Paulista de Avicultura), 1999. p.53-67.

FERNANDEZ, R.; LUCAS, E.; McGINNIS, J. Influence of diet composition on chick growth response to different antibiotics, feed additives and combination of the additives. Poultry Science, v.52, p.2299-2305, 1973.

FOOD AND DRUG ADMINISTRATION. A proposed assessment to evaluating and assuring human security to the effects of antimicrobial drugs in animal feeds. http://www.fda.gov/wm/fda/infores/vmac/ANTIM18.htm (14 june 1999). 
FUNK, M.A.; BAKER, D.H. Toxicity and tissue accumulation of copper in chicks fed casein and soy-based diets. Journal of Animal Science, v.69, p.4505$4511,1991$.

GOMES, J.D.F. A virginiamicina como estimulante do crescimento de suínos em recria. Piracicaba, 1991. 54p. Dissertação (Mestrado) - Escola Superior de Agricultura "Luiz de Queiroz", Universidade de São Paulo.

HAYS, V.H. National Academy of Sciences. The use of drugs in animal feeds. Proc of a Symp., Washington p. 11-31, 1969.

HAYS, V.W., SPEER, V.C. Effect of spiramycin on growth and feed utilization of young pigs. Journal of Animal Science v.19 p.983, 1960.

HAMBAKER, J.A.; DIAZ, V.; SPEER, V.C.; HAYS, V.W.; CATRON, D.V. The effect of oleandomycin ou the performance of the yong growing pig. Journal of Animal Science v.19, p.800, 1960.

HENRIQUE, A.P.F.; FARIA, D.E.; FRANZOLIN, R.; ITO, D.T. Uso de probiótico e antibióticos como promotores de crescimento para frango de corte. In: REUNIÃO ANUAL DA SOCIEDADE BRASILEIRA DE ZOOTECNIA, Botucatu, 1998. Anais. Botucatu: UNESP, 1998. p.297-299.

HENRY, P.R.; AMMERMAN, C.B.; CAMPBELL, D.R.; MILES, R.D. Effect of antibiotics on tissue trace mineral concentration and intestinal tract weight of broiler chicks. Poultry Science, v.66, p.1014-1018, 1987.

HILL, D.C.; BRANION, H.D.; SLINGER, S.J.; ANDERSON, G.W. Influence of environment on the growth response of chicks to penicillin. Poultry Science, v.32, p.462-475, 1952. 
HODA, A.A.; MAHA, M.H. Potency of copper as growth promoter in broiler chickens. Veterinary Medical Journal Giza, v. 43, n.1, p.77-85, 1995. /Resumo em CAB Abstracts on CD-ROM, 1995./

IZART, A.L.; THOMAS, R.A.; ADAMS, M.H. Marketing and produtcs. Poultry Science, v.68, p.651-655, 1989.

JENSEN, L.S.; MAURICE, D.V. Effect of high dietary copper on the ceca of chicks. Poultry Science, v.57, n.1, p.166-170, 1978.

JOHNSON, E.L.; NICHOLSON, J.L.; DOERR, J.A. Effect of dietary copper on litter microbial population and broiler performance. British Poultry Science, v.26, p.171-177, 1985.

JONG, E.V.; LEBOUTE, E.M.; CIOCCA, M.L.S.; PENZ JÚNIOR, A.M. Uso de avoparcina e virginiamicina como promotores de crescimento em raçōes para frango de corte. 1. Efeito sobre desempenho produtivo e utilização da energia da ração. Revista da Sociedade Brasileira de Zootecnia, v.14, n.5, p.529535, 1985.

JUNQUEIRA, O.M.; SAKOMURA, N.K.; BENJAMIN FILHO, F.B.; FARIA, D.E. Cloridrato de chorhexidina como promotor de crescimento para frangos de corte. Ciência Zootécnica, v.7, n.2, p.10-11, 1992.

KELLEY, K.W.; KENT, S.; DANTZER, R. Why sick animals don't grow. an immunological explanation. In: HOLLIS, G. R. (Ed.) Growth of the pig. Wallingford: $C A B$ International, 1993. p.119-132. 
KLASING, K.C.; LAURIN, D.E.; PENG, R.K.; FRY, D.M. Immunologically mediated growth depression in Chicks: Influence of Feed Intake, Corticosterone and Interleukin-1. Journal of Nutrition, v.117, p.1629-1637, 1987.

KRINKE, A.L.; JAMROZ, D. Effects of feed antibiotic avoparcine on organ morphology in broiler chickens. Poultry Science, v.75, p.705-710, 1996.

LEDOUX, D.R.; HENRY, P.R.; AMMERMAN, C.B.; RAO, P.V.; MILES, R.D. Estimation of the relative biovailability of inorganic copper sources for chicks using tissue uptake of copper. Journal of Animal Science, v.69, p.215-222, 1991.

LIMA, G.J.M.M. O papel do nutricionista no controle da poluição ambiental por dejetos de suínos. In: SIMPÓSIO LATINO AMERICANO DE SUÍNOS E AVES, Campinas, 1996. Anais. Campinas: Colégio Brasileiro de Nutrição Animal, 1996. p.118-132.

LIMA, I.A.V. Estudo de altos níveis de cobre orgânico e inorgânico como promotores de crescimento de leitões. Piracicaba, 1999. 51p. (Mestrado) Escola Superior de Agricultura "Luiz de Queiroz" - Universidade de São Paulo.

MACARI, M.; FURLAN, R.L.; GONZALES, E. Fisiologia aviária aplicada a frangos de corte. Jaboticabal: FUNEP, 1994. P. 175-199.

MacNAB, J.M. The avian caeca: A review. World's Poultry Science Journal, v.29, n.3, p.251-263, 1973.

MARCH, B.E. The host and its microflora: an ecological unit. Journal of Animal Science, v.49, n.3, p.857-867, 1979. 
MARCH, B.E.; SOONG, R.; MACMILLAN, C. Growth rate, feed coversion, and dietary metabolizable energy in response to virginiamycin supplementation of different diets. Poultry Science, v.57, p.1346-1350, 1978.

MAYNARD, L.A.; LOOSLI, J.K.; HINTZ, H.F.; WAGNER, R.G. Nutrição animal. 3. ed. Rio de Janeiro: Livraria Freitas Bastos, 1984. 726p.

McKAY, W.M. The use of antibiotics in animal feeds in the UK. The impact and importance of legislative controls. World's Poultry Science Journal, v.31, n.2, p.116-128, 1975.

MEHRING JÚNIOR, A.L.; BRUMBAUGH, J.H.; SUTHERLAND, A.J.; TITUS, H.W. The tolerance of growing chickens for dietary copper. Poultry Science, v.39, p.713-719, 1960.

MENTEN, J.F.M. Eficácia, efeito sinérgico e modo de ação de agentes antimicrobianos como promotores de crescimento em suínos. Piracicaba, 1995. 106p., Tese (Livre Docência) - Escola Superior de Agricultura "Luiz de Queiroz", Universidade de São Paulo.

MERCK \& CO. The Merck index: 11 ed. Rahway, 1985. 412p.

MILES, R.D.; JANKY, D.M.; HARMS, R.H. Virginiamycin and broiler performance. Poultry Science, v.63, p.1218-1221, 1984.

MILLES, R.D.; BROWN JÚNIOR., R.D. ; COMER, C.W; OELFKE, E. Influence of an enzyme and antibiotic on broiler performance. Journal of Applied Animal Research, v.9, n.2, p.105-117, 1996./Resumo em CAB abstracts on CD-ROM, 1996-1998/. 
MILLES, R.D.; O'KEEFE, S.F.; HENRY, P.R.; AMMERMAN, C.B.; LUO, X.G. The effect of dietary supplementation with copper sulfate or tribasic copper chloride on broiler performance, relative copper bioavailability, and dietary prooxidant activity. Poultry Science, v.77, p.416-425, 1998.

MONSON, W.J.; HARPER, A.E.; WINJE, M.E.; ELVEHJEM, C.A. A mechanism of the vitamin-sparing effect of antibiotics. Journal of Nutrition, v.52, p.627636, 1954.

MORAIS, S.C.D. Avaliação do desempenho e colesterol sérico e muscular de frangos de corte alimentados com níveis crescentes de citrato cúprico na dieta. Piracicaba, 1999. 74p. Dissertação (Mestrado) - Escola Superior de Agricultura "Luiz de Queiroz", Universidade de São Paulo.

MUDD, T. Fedd antibiotics:do they have a future? Feed Mix, v.5, n.1, p.18-20, 1997.

NATIONAL RESEARCH COUNCIL. Nutrient requeriments of poultry. 9:ed. Washington: National Academic Press, 1994. 71p.

OMETTO, J.C. Registros e estimativas de parâmetros meteorológicos da região de Piracicaba, SP. Piracicaba: FEALQ, 1989. 76 p.

PAGANINI, F.J. Cama de frangos. Anuário da Avicultura Industrial, v.90, n.1074, p.76-77, dez. 1999/jan.2000.

PELCZAR JÚNIOR, M.J.; CHAN, E.C.S.; KRUG, N.R. Microbiologia: conceitos e aplicações. 2. ed. São Paulo: Makron books do Brasil 1996. $517 \mathrm{p}$. 
PESTI, M.P.; BAKALLI, R.I. Studies on the feeding of cupric sulfate pentahydrate and cupric citrate to broiler chickens. Poultry Science, v.75, p.1086-1091, 1996.

POUPOULIS, C.; JENSEN, L.S. Effect of high dietary copper on gizzard integrity of the chick. Poultry Science, v.55, p.113-121, 1976.

ROSTAGNO, H.S.; SILVA, M.A. Pesquisas recentes em nutrição de aves e suínos. In: ENCONTRO TÉCNICO MICOTOXINAS E PROMOTORES DE CRESCIMENTO, 1., Campinas, 1998. Campinas: Stallen, 1998. p. 5-30.

ROSTAGNO, H.S.; SILVA, D.J.; COSTA, D.M.A. FONSECA, J.B.; SOARES, P.R. PEREIRA, J.A.A; SILVA, M.A. Composição de alimentos e exigências nutricionais de aves e suínos (tabelas braseileiras) Viçosa: UFV, Imp. Univ, $198359 p$.

ROURA, E.; HOMEDES, J.; KLASING, K.C. Prevention of Immunologic Stress Contributes to the Growth-Permitting Ability of Dietary Antibiotics in Chicks. Journal of Nutrition, v.122, p.2383-2390, 1992.

SALANITRO, J.P.; BLAKE, I.G.; MUIRHEAD, P.A.; MAGLIO, M.; GOODMAN, J.R. Bacteria isolated from the duodenum, ileum, and cecum of yong chicks. Applied and Enviroment Microbiology, v.35, n.4, p.782-790, 1978.

SAS INSTITUTE. SAS/STAT: user's guide, version 6: Cary, 19891686 p.

SHURSON, G.C.; KU, P.K.; WAXLER, G.L.; YOKOYAMA, M.T.; MILLER, E.R. Physiological relationsphips betwenn microbiological statu and dietary copper levels in the pig. Journal of Animal Science, v.68, p.1061-1071, 1990. 
SINDAN (SINDICATO NACIONAL DA INDÚSTRIA DOS PRODUTOS PARA SAÚDE ANIMAL). $O$ uso adequado de antimicrobianos como aditivos melhoradores da eficiência alimentar em animais de produção. São paulo, 1999, 1v.

SMITH, H.W. Antibiotic - resistance bacteria im animals: The danger to human health. World's Poultry Science Journal, v.31, n.2, p.105-115, 1975.

SOARES, L.L.P. Painel: restrições e uso de aditivos (promotores de crescimento) em rações de aves. Visão do fabricante. In: CONFERÊNCIA APINCO DE CIÊNCIA E TECNOLOGIA AVÍCOLAS, Curitiba, 1996. Anais. Campinas: FACTA, 1996. p.27-36.

SONCINI, R.A. Restrições do uso de aditivos na alimentação animal expectativa da agroindústria. In: SIMPÓSIO SOBRE AS IMPLICAÇÕES SÓCIO-ECONÔMICAS DO USO DE ADITIVOS NA PRODUÇÃO ANIMAL, Campinas, 1999. Anais. Campinas: Colégio Brasileiro de Nutrição Animal, 1999. p. 99-104.

STAHLY, T.S.; CROMWELL, G.L.; MONEGUE, H.J. Effects of the dietary inclusion of copper and (or) antibiotics on the performance of weanling pigs. Journal of Animal Science, v.51, n.6, p.1347-1351, 1980.

STANSBURY, W.F.; TRIBBLE, L.F.; ORR JR, D.E. Effect of chelated copper souces on performance of nursery and growing pigs. Journal of Animal Science, v.68, p.1318-1322, 1990.

STARCHER, B.C. Studies on the mechanism of copper absorption in the chick. Journal of Nutrition, v.97, p.321-326, 1969. 
STUTZ, M.W.; LAWTON, G.C. Effects of diet and antimicrobials on growth, feed efficiency, intestinal Clostridium perfringens, and ileal weight of broiler chicks. Poultry Science, v.63, p.2036-2042, 1984.

VISEK, W.J. The mode of growth promotion by antibiotics. Poultry Science, v.46, p.1447-1469. 1978.

YEN, J.T.; NIENABER, J.A. Effects of high-copper feeding on portal ammonia absorpition and on oxygen consumption by vein-drained organs and by the whole animal in growing pigs. Journal of Animal Science, v.71, n.2157-2163, 1993.

YEN, J.T.; POND, W.G. Effect of carbadox on net absortion of ammonia and glucose into hepatic portal vein of growing pigs. Journal of Animal Science, v.68, n.4236-4242, 1990.

ZHONG, S.J.; XILONG, X.; BEILEI, Z.; Studies on the growth-promoting effect of virginiamycin on broilers. Acta-Agriculturae-Universitatis-Pekinensis. v.21, n.1, p.100-103, 1995. / Resumo em CAB abstracts on CD-ROM, 1995.

ZHOU, W.; KORNEGAY, E.T.; LARR, H.V.; SWINKELS, J.W.G.M.; WONG, E.A.; LINDEMANN, M.D. The role of feed consumption and feed efficiency in copper-stimulated growth. Journal of Animal Science, v.72, p.2385-2394, $1994 a$.

ZHOU, W.; KORNEGAY, M.D.; LINDEMANN, M.D.; SWINKELS, J.W.G.M.; WELTEN, M.K.; WONG, E.A. Stimulation of growth by intravenous injection of copper in weanling pigs. Journal of Animal Science, v.72, p.2395-2403, 1994b. 
ZINPRO CORPORATION Evaluation of Cuplex® copper lysine additions in starter pig diets. http://urww.zimpro.com (08 aug. 1999).

ZUANON, J.A.S.; FONSECA, J.B.; ROSTAGNO, H.S.; SILVA, M.A. Desempenho de frangos de corte alimentados com rações contendo antibiótico e probiótico adicionados isoladamente, associados e em uso sequencial. Revista Brasileira de Zootecnia, v.27, n.5, p.994-998, 1998. 


\section{APÊNDICE}

Apêndice 1. Peso vivo médio $(\mathrm{kg})$ semanal dos frangos de corte

\begin{tabular}{|c|c|c|c|c|c|c|c|c|}
\hline \multirow[b]{2}{*}{ TRATAMENTO } & \multirow[b]{2}{*}{ BLOCO } & \multicolumn{7}{|c|}{ DIAS } \\
\hline & & 1 & 7 & 14 & 21 & 28 & 35 & 42 \\
\hline \multirow{7}{*}{ CONTROLE } & 1 & 0,0398 & 0,1489 & 0,3700 & 0,7430 & 1,2310 & 1,7460 & 2,3440 \\
\hline & 2 & 0,0400 & 0,1530 & 0,3750 & 0,7540 & 1,2580 & 1,7920 & 2,3840 \\
\hline & 3 & 0,0400 & 0,1472 & 0,3690 & 0,7410 & 1,2260 & 1,7630 & 2,3530 \\
\hline & 4 & 0,0395 & 0,1453 & 0,3830 & 0,7830 & 1,2830 & 1,7970 & 2,3970 \\
\hline & 5 & 0,0403 & 0,1524 & 0,3580 & 0,7380 & 1,2150 & 1,7670 & 2,3350 \\
\hline & 6 & 0,0398 & 0,1538 & 0,3790 & 0,7720 & 1,2640 & 1,8160 & 2,3840 \\
\hline & MEDIA & 0,0399 & 0,1501 & 0,3723 & 0,7552 & 1,2462 & 1,7802 & 2,3662 \\
\hline \multirow{7}{*}{ SULFATO } & 1 & 0,0408 & 0,1492 & 0,3720 & 0,7590 & 1,2760 & 1,8110 & 2,4440 \\
\hline & 2 & 0,0398 & 0,1534 & 0,3680 & 0,7400 & 1,2380 & 1,7850 & 2,3920 \\
\hline & 3 & 0,0400 & 0,1465 & 0,3480 & 0,7130 & 1,2150 & 1,7810 & 2,3580 \\
\hline & 4 & 0,0390 & 0,1480 & 0,3550 & 0,7290 & 1,2290 & 1,7760 & 2,3410 \\
\hline & 5 & 0,0400 & 0,1501 & 0,3740 & 0,7560 & 1,2410 & 1,7760 & 2,3540 \\
\hline & 6 & 0,0398 & 0,1532 & 0,3690 & 0,7720 & 1,2620 & 1,8050 & 2,3660 \\
\hline & MÉDIA & 0,0399 & 0,1501 & 0,3643 & 0,7448 & 1,2435 & 1,7890 & 2,3758 \\
\hline \multirow{7}{*}{ CITRATO } & 1 & 0,0400 & 0,1465 & 0,3560 & 0,7410 & 1,2380 & 1,7670 & 2,3890 \\
\hline & 2 & 0,0398 & 0,1480 & 0,3580 & 0,7380 & 1,2200 & 1,7640 & 2,4160 \\
\hline & 3 & 0,0400 & 0,1455 & 0,3750 & 0,7750 & 1,2600 & 1,7950 & 2,3730 \\
\hline & 4 & 0,0395 & 0,1474 & 0,3550 & 0,7380 & 1,2050 & 1,7170 & 2,3200 \\
\hline & 5 & 0,0400 . & 0,1526 & 0,3750 & 0,7600 & 1,2500 & 1,7750 & 2,3920 \\
\hline & 6 & 0,0398 & 0,1460 & 0,3550 & 0,7280 & 1,2020 & 1,7450 & 2,3440 \\
\hline & MÉDIA & 0,0398 & 0,1477 & 0,3623 & 0,7467 & 1,2292 & 1,7605 & 2,3723 \\
\hline \multirow{7}{*}{ VM } & 1 & 0,0398 & 0,1523 & 0,3800 & 0,7680 & 1,2800 & 1,8130 & 2,4280 \\
\hline & 2 & 0,0395 & 0,1508 & 0,3730 & 0,7430 & 1,2400 & 1,7630 & 2,3540 \\
\hline & 3 & 0,0400 & 0,1519 & 0,3730 & 0,7580 & 1,2500 & 1,7750 & 2,3590 \\
\hline & 4 & 0,0395 & 0,1480 & 0,3640 & 0,7460 & 1,2400 & 1,7490 & 2,3500 \\
\hline & 5 & 0,0403 & 0,1483 & 0,3590 & 0,7550 & 1,2660 & 1,8180 & 2,4290 \\
\hline & 6 & 0,0395 & 0,1541 & 0,3850 & 0,7800 & 1,2480 & 1,7720 & 2,3260 \\
\hline & MÉDIA & 0,0398 & 0,1509 & 0,3723 & 0,7583 & 1,2540 & 1,7817 & 2,3743 \\
\hline \multirow{7}{*}{$\begin{array}{l}\text { CITRATO } \\
+ \text { VM }\end{array}$} & 1 & 0,0403 & 0,1571 & 0,3900 & 0,7800 & 1,2730 & 1,7780 & 2,3780 \\
\hline & 2 & 0,0400 & 0,1479 & 0,3780 & 0,7650 & 1,2350 & 1,7650 & 2,3500 \\
\hline & 3 & 0,0410 & 0,1518 & 0,3760 & 0,7700 & 1,2560 & 1,8000 & 2,4000 \\
\hline & 4 & 0,0395 & 0,1480 & 0,3670 & 0,7640 & 1,2280 & 1,7790 & 2,3690 \\
\hline & 5 & 0,0403 & 0,1513 & 0,3730 & 0,7700 & 1,2650 & 1,7950 & 2,3930 \\
\hline & 6 & 0,0398 & 0,1470 & 0,3550 & 0,7380 & 1,2030 & 1,7350 & 2,2620 \\
\hline & MÉDIA & 0,0401 & 0,1505 & 0,3732 & 0,7645 & 1,2433 & 1,7753 & 2,3587 \\
\hline
\end{tabular}


Apêndice 2. Ganho médio de peso $(\mathrm{kg})$ semanal dos frangos de corte

\begin{tabular}{|c|c|c|c|c|c|c|c|}
\hline \multirow{2}{*}{ TRATAMENTO } & \multirow[b]{2}{*}{ BLOCO } & \multicolumn{6}{|c|}{ DIAS } \\
\hline & & 7 & 14 & 21 & 28 & 35 & 42 \\
\hline \multirow{7}{*}{ CONTROLE } & 1 & 0,109 & 0,221 & $\overline{0,373}$ & 0,488 & 0,515 & 0,598 \\
\hline & 2 & 0,113 & 0,222 & 0,379 & 0,504 & 0,534 & 0,592 \\
\hline & 3 & 0,107 & 0,222 & 0,372 & 0,485 & 0,537 & 0,590 \\
\hline & 4 & 0,106 & 0,238 & 0,400 & 0,500 & 0,514 & 0,600 \\
\hline & 5 & 0,112 & 0,206 & 0,380 & 0,477 & 0,552 & 0,568 \\
\hline & 6 & 0,114 & 0,225 & 0,393 & 0,492 & 0,552 & 0,568 \\
\hline & MEDIA & 0,110 & 0,222 & 0,383 & 0,491 & 0,534 & 0,586 \\
\hline \multirow{7}{*}{ SULFATO } & 1 & 0,108 & 0,223 & 0,387 & 0,517 & 0,535 & 0,633 \\
\hline & 2 & 0,114 & 0,215 & 0,372 & 0,498 & 0,547 & 0,607 \\
\hline & 3 & 0,107 & 0,202 & 0,365 & 0,502 & 0,566 & 0,577 \\
\hline & 4 & 0,109 & 0,207 & 0,374 & 0,500 & 0,547 & 0,565 \\
\hline & 5 & 0,110 & 0,224 & 0,382 & 0,485 & 0,535 & 0,578 \\
\hline & 6 & 0,113 & 0,216 & 0,403 & 0,490 & 0,543 & 0,561 \\
\hline & MÉDIA & 0,110 & 0,214 & 0,381 & 0,499 & 0,546 & 0,587 \\
\hline \multirow{7}{*}{ CITRATO } & 1 & 0,107 & 0,209 & 0,385 & 0,497 & 0,529 & 0,622 \\
\hline & 2 & 0,108 & 0,210 & 0,380 & 0,482 & 0,544 & 0,652 \\
\hline & 3 & 0,106 & 0,230 & 0,400 & 0,485 & 0,535 & 0,578 \\
\hline & 4 & 0,108 & 0,208 & 0,383 & 0,467 & 0,512 & 0,603 \\
\hline & 5 & 0,113 & 0,222 & 0,385 & 0,490 & 0,525 & 0,617 \\
\hline & 6 & 0,106 & 0,209 & 0,373 & 0,474 & 0,543 & 0,599 \\
\hline & MÉDIA & 0,108 & 0,215 & 0,384 & 0,483 & 0,531 & 0,612 \\
\hline \multirow{7}{*}{ VM } & 1 & 0,113 & 0,228 & 0,388 & 0,512 & 0,533 & 0,615 \\
\hline & 2 & 0,111 & 0,222 & 0,370 & 0,497 & 0,523 & 0,591 \\
\hline & 3 & 0,112 & 0,221 & 0,385 & 0,492 & 0,525 & 0,584 \\
\hline & 4 & 0,108 & 0,216 & 0,382 & 0,494 & 0,509 & 0,601 \\
\hline & 5 & 0,108 & 0,211 & 0,396 & 0,511 & 0,552 & 0,611 \\
\hline & 6 & 0,115 & 0,231 & 0,395 & 0,468 & 0,524 & 0,554 \\
\hline & MÉDIA & 0,111 & 0,221 & 0,386 & 0,496 & 0,528 & 0,593 \\
\hline \multirow{7}{*}{$\begin{array}{l}\text { CITRATO } \\
+ \text { VM }\end{array}$} & 1 & 0,117 & 0,233 & 0,390 & 0,493 & 0,505 & 0,600 \\
\hline & 2 & 0,108 & 0,230 & 0,387 & 0,470 & 0,530 & 0,585 \\
\hline & 3 & 0,111 & 0,224 & 0,394 & 0,486 & 0,544 & 0,600 \\
\hline & 4 & 0,109 & 0,219 & 0,397 & 0,464 & 0,551 & 0,590 \\
\hline & 5 & 0,111 & 0,222 & 0,397 & 0,495 & 0,530 & 0,598 \\
\hline & 6 & 0,107 & 0,208 & 0,383 & 0,465 & 0,532 & 0,527 \\
\hline & MEDDIA & 0,110 & 0,223 & 0,391 & 0,479 & 0,532 & 0,583 \\
\hline
\end{tabular}


Apêndice 3. Consumo de ração médio corrigido $(\mathrm{kg})$ semanal dos frangos de corte

\begin{tabular}{|c|c|c|c|c|c|c|c|}
\hline \multirow[b]{2}{*}{ TRATAMENTO } & \multirow[b]{2}{*}{ BLOCO } & \multicolumn{6}{|c|}{ DIAS } \\
\hline & & 7 & 14 & 21 & 28 & 35 & 42 \\
\hline \multirow{7}{*}{ CONTROLE } & 1 & 0,160 & 0,425 & 0,720 & 0,933 & 1,076 & 1,303 \\
\hline & 2 & 0,166 & 0,396 & 0,675 & 0,905 & 1,082 & 1,278 \\
\hline & 3 & 0,165 & 0,393 & 0,705 & 0,889 & 1,127 & 1,268 \\
\hline & 4 & 0,162 & 0,415 & 0,605 & 0,917 & 1,114 & 1,315 \\
\hline & 5 & 0,161 & 0,387 & 0,710 & 0,866 & 1,113 & 1,276 \\
\hline & 6 & 0,174 & 0,409 & 0,706 & 0,919 & 1,154 & 1,238 \\
\hline & MÉDIA & 0,165 & 0,404 & 0,687 & 0,905 & 1,111 & 1,280 \\
\hline \multirow{7}{*}{ SULFATO } & 1 & 0,162 & 0,407 & 0,713 & 0,907 & 1,103 & 1,321 \\
\hline & 2 & 0,159 & 0,403 & 0,680 & 0,920 & 1,148 & 1,305 \\
\hline & 3 & 0,154 & 0,367 & 0,707 & 0,892 & 1,146 & 1,255 \\
\hline & 4 & 0,167 & 0,426 & 0,745 & 0,922 & 1,101 & 1,236 \\
\hline & 5 & 0,161 & 0,394 & 0,721 & 0,891 & 1,116 & 1,221 \\
\hline & 6 & 0,161 & 0,400 & 0,700 & 0,907 & 1,123 & 1,219 \\
\hline & MÉDIA & 0,161 & 0,400 & 0,711 & 0,907 & 1,123 & 1,259 \\
\hline \multirow{7}{*}{ CITRATO } & 1 & 0,156 & 0,405 & 0,672 & 0,887 & 1,077 & 1,300 \\
\hline & 2 & 0,161 & 0,418 & 0,733 & 0,891 & 1,090 & 1,312 \\
\hline & 3 & 0,166 & 0,424 & 0,680 & 0,896 & 1,083 & 1,261 \\
\hline & 4 & 0,168 & 0,396 & 0,810 & 0,766 & 1,228 & 1,296 \\
\hline & 5 & 0,170 & 0,418 & 0,733 & 0,908 & 1,080 & 1,273 \\
\hline & 6 & 0,156 & 0,399 & 0,733 & 0,850 & 1,080 & 1,226 \\
\hline & MEDDIA & 0,163 & 0,410 & 0,726 & 0,866 & 1,106 & 1,278 \\
\hline \multirow{7}{*}{ VM } & 1 & 0,151 & 0,396 & 0,638 & 0,890 & 1,085 & 1,283 \\
\hline & 2 & 0,163 & 0,415 & 0,670 & 0,884 & 1,045 & 1,230 \\
\hline & 3 & 0,162 & 0,412 & 0,708 & 0,894 & 1,078 & 1,266 \\
\hline & 4 & 0,161 & 0,394 & 0,738 & 0,921 & 1,049 & 1,253 \\
\hline & 5 & 0,154 & 0,429 & 0,713 & 0,899 & 1,087 & 1,288 \\
\hline & 6 & 0,164 & 0,401 & 0,680 & 0,883 & 1,079 & 1,193 \\
\hline & MÉDIA & 0,159 & 0,408 & 0,691 & 0,895 & 1,070 & 1,252 \\
\hline \multirow{7}{*}{$\begin{array}{l}\text { CITRATO } \\
+ \text { + VM }\end{array}$} & 1 & 0,165 & 0,433 & 0,688 & 0,910 & 1,050 & 1,290 \\
\hline & 2 & 0,151 & 0,390 & 0,703 & 0,894 & 1,060 & 1,202 \\
\hline & 3 & 0,165 & 0,408 & 0,682 & 0,919 & 1,111 & 1,260 \\
\hline & 4 & 0,166 & 0,410 & 0,713 & 0,905 & 1,108 & 1,287 \\
\hline & 5 & 0,161 & 0,414 & 0,668 & 0,900 & 1,093 & 1,290 \\
\hline & 6 & 0,161 & 0,399 & 0,728 & 0,873 & 1,084 & 1,216 \\
\hline & MÉDIA & 0,162 & 0,409 & 0,697 & 0,900 & 1,084 & 1,258 \\
\hline
\end{tabular}


Apêndice 4. Conversão Alimentar média semanal dos frangos de corte

\begin{tabular}{|c|c|c|c|c|c|c|c|}
\hline \multirow{2}{*}{ TRATAMENTO } & \multirow[b]{2}{*}{ BLOCO } & \multicolumn{6}{|c|}{ DIAS } \\
\hline & & 7 & 14 & 21 & 28 & 35 & 42 \\
\hline \multirow{7}{*}{ CONTROLE } & 1 & 1,470 & 1,924 & 1,930 & 1,912 & 2,089 & 2,179 \\
\hline & 2 & 1,470 & 1,784 & 1,781 & 1,797 & 2,027 & 2,159 \\
\hline & 3 & 1,539 & 1,773 & 1,896 & 1,833 & 2,099 & 2,149 \\
\hline & 4 & 1,533 & 1,745 & 1,512 & 1,834 & 2,167 & 2,191 \\
\hline & 5 & 1,436 & 1,883 & 1,868 & 1,815 & 2,017 & 2,247 \\
\hline & 6 & 1,527 & 1,814 & 1,797 & 1,868 & 2,091 & 2,179 \\
\hline & MÉDIA & 1,496 & 1,821 & 1,797 & 1,843 & 2,082 & 2,184 \\
\hline \multirow{7}{*}{ SULFATO } & 1 & 1,496 & 1,827 & 1,842 & 1,755 & 2,061 & 2,086 \\
\hline & 2 & 1,403 & 1,879 & 1,828 & 1,848 & 2,040 & 2,150 \\
\hline & 3 & 1,450 & 1,822 & 1,937 & 1,777 & 2,025 & 2,174 \\
\hline & 4 & 1,536 & 2,057 & 1,991 & 1,844 & 2,013 & 2,188 \\
\hline & 5 & 1,459 & 1,760 & 1,886 & 1,838 & 2,086 & 2,113 \\
\hline & 6 & 1,423 & 1,853 & 1,737 & 1,852 & 2,068 & 2,173 \\
\hline & MÉDIA & 1,461 & 1,866 & 1,870 & 1,819 & 2,049 & 2,147 \\
\hline \multirow{7}{*}{ CITRATO } & 1 & 1,467 & 1,935 & 1,745 & 1,785 & 2,036 & 2,090 \\
\hline & 2 & 1,486 & 1,990 & 1,928 & 1,849 & 2,003 & 2,013 \\
\hline & 3 & 1,576 & 1,849 & 1,699 & 1,846 & 2,023 & 2,181 \\
\hline & 4 & 1,558 & 1,906 & 2,115 & 1,641 & 2,397 & 2,150 \\
\hline & 5 & 1,507 & 1,880 & 1,903 & 1,853 & 2,057 & 2,062 \\
\hline & 6 & 1,467 & 1,907 & 1,964 & 1,792 & 1,989 & 2,047 \\
\hline & MÉDIA & 1,510 & 1,911 & 1,892 & 1,794 & 2,084 & 2,090 \\
\hline \multirow{7}{*}{ VM } & 1 & 1,346 & 1,739 & 1,643 & 1,738 & 2,036 & 2,085 \\
\hline & 2 & 1,466 & 1,869 & 1,811 & 1,778 & 1,998 & 2,080 \\
\hline & 3 & 1,448 & 1,864 & 1,838 & 1,818 & 2,052 & 2,168 \\
\hline & 4 & 1,484 & 1,822 & 1,933 & 1,865 & 2,060 & 2,084 \\
\hline & 5 & 1,428 & 2,042 & 1,800 & 1,759 & 1,969 & 2,108 \\
\hline & 6 & 1,431 & 1,738 & 1,722 & 1,886 & 2,060 & 2,153 \\
\hline & MEDIA & 1,434 & 1,846 & 1,791 & 1,807 & 2,029 & 2,113 \\
\hline \multirow{7}{*}{$\begin{array}{l}\text { CITRATO } \\
+ \text { VM }\end{array}$} & 1 & 1,411 & 1,859 & 1,763 & 1,846 & 2,079 & 2,150 \\
\hline & 2 & 1,403 & 1,696 & 1,815 & 1,903 & 2,000 & 2,054 \\
\hline & 3 & 1,488 & 1,821 & 1,732 & 1,891 & 2,042 & 2,100 \\
\hline & 4 & 1,531 & 1,872 & 1,796 & 1,951 & 2,010 & 2,182 \\
\hline & 5 & 1,452 & 1,868 & 1,681 & 1,819 & 2,061 & 2,158 \\
\hline & 6 & 1,501 & 1,919 & 1,899 & 1,877 & 2,038 & 2,308 \\
\hline & MÉDIA & 1,464 & 1,839 & 1,781 & 1,881 & 2,038 & 2,159 \\
\hline
\end{tabular}


Apêndice 5. Mortalidade (M) e refugagem (R) dos frangos de corte (1 a 42 dias)

\begin{tabular}{|c|c|c|c|c|c|c|c|}
\hline \multirow{3}{*}{ TRATAMENTO } & \multirow{3}{*}{ BLOCO } & \multicolumn{6}{|c|}{ Dias } \\
\hline & & 7 & 14 & 21 & 28 & 35 & 42 \\
\hline & & M R & $M \quad R$ & $\begin{array}{ll}M & R \\
\end{array}$ & $M \quad R$ & $M \quad R$ & $\bar{M} \mathbf{R}$ \\
\hline \multirow{6}{*}{ CONTROLE } & 1 & - & - & - & - & 1 & - \\
\hline & 2 & - & - & 1 & 1 & 1 & - \\
\hline & 3 & - & $\begin{array}{ll}- & -\end{array}$ & & - & - & - \\
\hline & 4 & - & - $\quad-$ & & & - & - \\
\hline & 5 & $-\quad-$ & $\begin{array}{ll}- & - \\
- & -1\end{array}$ & $-\quad-$ & - & - & - \\
\hline & 6 & $-\quad-$ & $1-$ & $-\quad-$ & $-\quad-$ & $-\quad 1$ & $-\quad-$ \\
\hline \multirow{2}{*}{ TOTAL } & $n^{0}$ aves & & & & & 6 & 0 \\
\hline & $\%$ & 0 & 0,42 & 0,42 & 0,42 & 2,5 & 0 \\
\hline \multirow{6}{*}{ SULFATO } & 1 & $-\quad-$ & $-\quad-$ & $-\quad-$ & $1-$ & $-\quad-$ & $\begin{array}{ll}1 & 1\end{array}$ \\
\hline & 2 & $-\quad-$ & $-\quad-$ & - & - & - & -1 \\
\hline & 3 & $-\quad-$ & $-\quad-$ & - & 1 & 1 & \\
\hline & 4 & $\begin{array}{ll}- & - \\
- & -\end{array}$ & & & - & & \\
\hline & 5 & - & & & & - & - \\
\hline & 6 & $-\quad-$ & $-\quad-$ & $-\quad-$ & $-\quad-$ & $2-$ & $-\quad-$ \\
\hline \multirow[t]{2}{*}{ TOTAL } & $n^{-}$aves & 0 & 1 & 2 & 2 & 7 & 3 \\
\hline & $\frac{\%}{1}$ & 0 & $\frac{0,42}{-}$ & $\frac{0,83}{-}$ & $\frac{0,83}{--}$ & $\frac{2,92}{-}-$ & $\frac{1,25}{-}$ \\
\hline \multirow{5}{*}{ CITRATO } & 2 & - & & 1 & & & -1 \\
\hline & 3 & & & - & & & \\
\hline & 4 & & - & - & - & - & \\
\hline & 5 & & & & & & \\
\hline & 6 & & $-\quad-$ & - & - & & \\
\hline \multirow{2}{*}{ TOTAL } & $\mathrm{n}^{-}$aves & 0 & 0 & 1 & 0 & 0 & 2 \\
\hline & $\%$ & 0 & 0 & 0,42 & 0 & 0 & 0,83 \\
\hline \multirow{6}{*}{ VM } & 1 & $-\quad-$ & & & & $-\quad-$ & - \\
\hline & 2 & $-\quad-$ & & & & - & \\
\hline & 3 & $-\quad-$ & - & & & & - \\
\hline & 4 & $-\quad-$ & - & - & - & & 1 \\
\hline & 5 & $-\quad-$ & 2 & - & - & & - \\
\hline & 6 & $-\quad-$ & $-\quad-$ & - & $-\quad-$ & $-\quad 1$ & $-\quad-$ \\
\hline \multirow{2}{*}{ TOTAL } & $\mathrm{n}^{\mathrm{v}}$ aves & 0 & 2 & 0 & 0 & 1 & 2 \\
\hline & $\%$ & 0 & 0,83 & 0 & 0 & 0,42 & 0,83 \\
\hline \multirow{6}{*}{$\begin{array}{l}\text { CITRATO } \\
\text { + VM }\end{array}$} & 1 & & & & & & $-\quad-$ \\
\hline & 2 & $\begin{array}{l}- \\
-\end{array}$ & & & & & \\
\hline & 3 & - & - & - & - & - & - \\
\hline & 4 & $-\quad-$ & & & & & - \\
\hline & 5 & $-\quad-$ & & - & - & - & - \\
\hline & 6 & $-\quad-$ & $-\quad-$ & $-\quad-$ & $-\quad-$ & $3-$ & $-\quad-$ \\
\hline \multirow{2}{*}{ TOTAL } & no aves & 0 & 1 & 0 & 0 & 3 & 0 \\
\hline & $\%$ & 0 & 0,42 & 0 & 0 & 1,25 & 0 \\
\hline
\end{tabular}


Apêndice 6. Temperatura retal média $\left({ }^{\circ} \mathrm{C}\right)$ semanal dos frangos de corte

\begin{tabular}{|c|c|c|c|c|c|c|c|}
\hline \multirow{2}{*}{ TRATAMENTO } & \multirow[b]{2}{*}{ BLOCO } & \multicolumn{6}{|c|}{ DIAS } \\
\hline & & 7 & 14 & 21 & 28 & 35 & 42 \\
\hline \multirow{7}{*}{ CONTROLE } & 1 & 41,373 & 41,675 & 41,883 & 41,350 & 42,005 & 42,090 \\
\hline & 2 & 41,060 & 41,753 & 41,725 & 41,745 & 41,585 & 42,043 \\
\hline & 3 & 41,455 & 41,683 & 41,665 & 41,948 & 42,025 & 42,030 \\
\hline & 4 & 41,208 & 41,643 & 41,890 & 42,230 & 42,265 & 42,315 \\
\hline & 5 & 41,313 & 41,743 & 41,798 & 42,218 & 42,060 & 42,105 \\
\hline & 6 & 41,478 & 41,705 & 41,830 & 42,065 & 41,918 & 42,013 \\
\hline & MÉDIA & 41,314 & 41,700 & 41,798 & 41,926 & 41,976 & 42,099 \\
\hline \multirow{7}{*}{ SULFATO } & 1 & 41,190 & 41,640 & 41,690 & 41,640 & 41,888 & 41,658 \\
\hline & 2 & 41,065 & 41,508 & 41,555 & 41,730 & 41,700 & 41,980 \\
\hline & 3 & 41,355 & 41,738 & 41,700 & 41,960 & 42,073 & 42,060 \\
\hline & 4 & 41,440 & 41,825 & 41,745 & 41,938 & 41,970 & 41,938 \\
\hline & 5 & 41,050 & 41,745 & 41,693 & 42,135 & 42,068 & 42,133 \\
\hline & 6 & 41,158 & 41,715 & 41,630 & 41,930 & 42,120 & 41,998 \\
\hline & MÉDIA & 41,210 & 41,695 & 41,669 & 41,889 & 41,970 & 41,961 \\
\hline \multirow{7}{*}{ CITRATO } & 1 & 41,230 & 41,553 & 41,445 & 41,820 & 42,183 & 42,090 \\
\hline & 2 & 41,180 & 41,523 & 41,860 & 41,698 & 42,055 & 41,740 \\
\hline & 3 & 41,075 & 41,828 & 41,718 & 41,638 & 42,260 & 41,955 \\
\hline & 4 & 41,303 & 41,998 & 41,588 & 41,778 & 41,693 & 41,588 \\
\hline & 5 & 41,425 & 41,613 & 41,840 & 41,780 & 42,013 & 41,503 \\
\hline & 6 & 41,168 & 41,995 & 41,783 & 41,975 & 42,110 & 42,220 \\
\hline & MÉDIA & 41,230 & 41,751 & 41,705 & 41,781 & 42,052 & 41,849 \\
\hline \multirow{7}{*}{ VM } & 1 & 40,840 & 41,845 & 41,898 & 41,843 & 42,025 & 41,793 \\
\hline & 2 & 41,590 & 41,870 & 41,665 & 41,685 & 41,875 & 41,795 \\
\hline & 3 & 40,775 & 41,973 & 43,090 & 41,990 & 42,375 & 41,983 \\
\hline & 4 & 41,243 & 41,798 & 41,578 & 41,790 & 41,740 & 41,655 \\
\hline & 5 & 41,353 & 41,708 & 41,563 & 42,160 & 41,860 & 42,063 \\
\hline & 6 & 41,208 & 41,745 & 41,788 & 42,228 & 41,955 & 42,175 \\
\hline & MEDIA & 41,168 & 41,823 & 41,930 & 41,949 & 41,972 & 41,910 \\
\hline \multirow{7}{*}{$\begin{array}{l}\text { CITRATO } \\
+ \text { VM }\end{array}$} & 1 & 41,270 & 41,458 & 41,728 & 41,390 & 42,135 & 41,803 \\
\hline & 2 & 40,758 & 41,680 & 41,843 & 41,458 & 42,005 & 41,980 \\
\hline & 3 & 41,150 & 41,658 & 41,785 & 41,790 & 41,783 & 42,015 \\
\hline & 4 & 41,430 & 41,775 & 41,773 & 41,600 & 41,793 & 42,030 \\
\hline & 5 & 41,420 & 41,668 & 41,765 & 41,843 & 41,753 & 41,418 \\
\hline & 6 & 41,283 & 41,855 & 41,898 & 41,840 & 41,990 & 42,028 \\
\hline & MÉDIA & 41,218 & 41,682 & 41,798 & 41,653 & 41,910 & 41,879 \\
\hline
\end{tabular}


Apêndice 7. Temperaturas mínimas e máximas observadas no aviário durante o período experimental ( 1 a 42 dias)

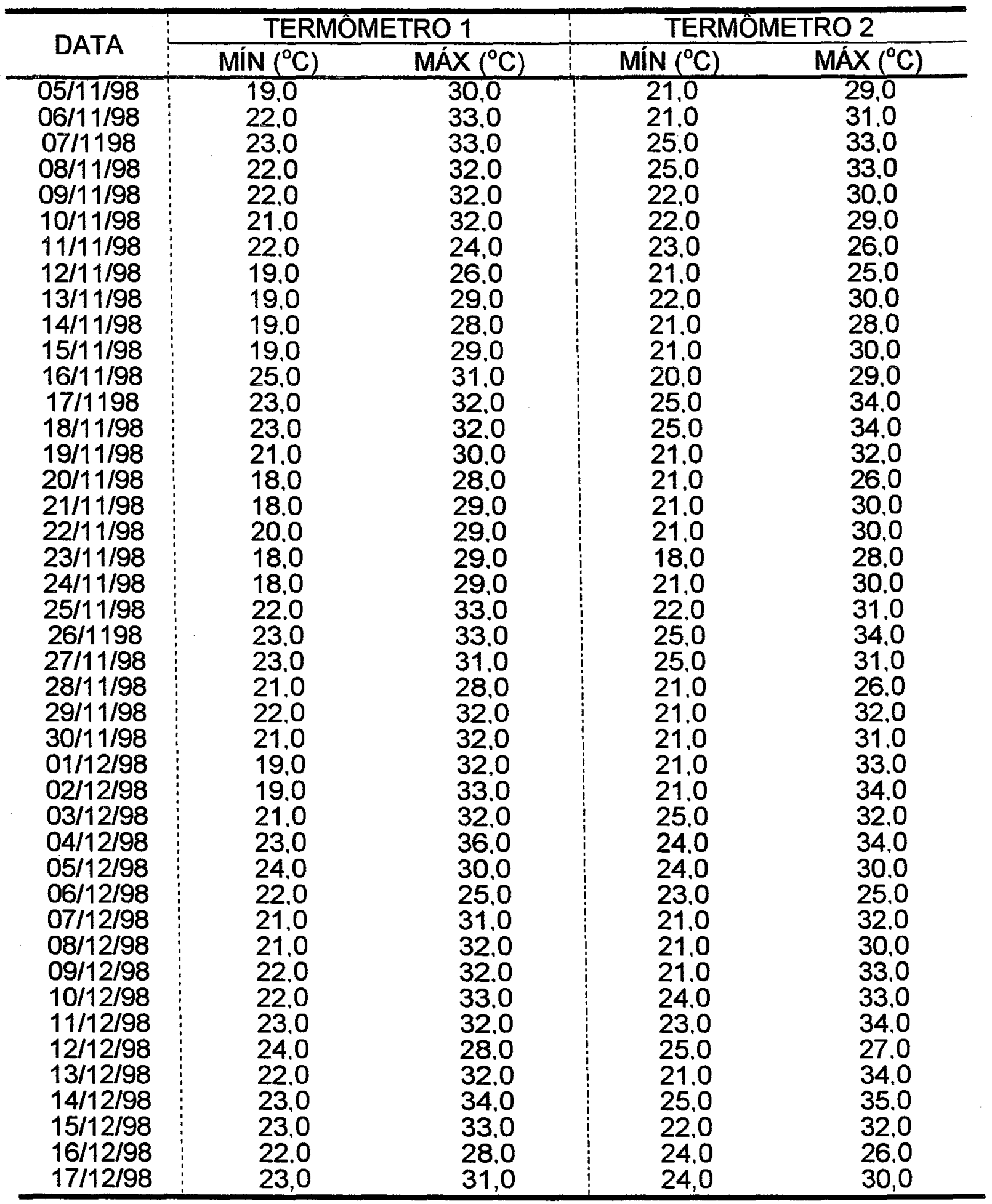


Apêndice 8. Esquema do galpão experimental

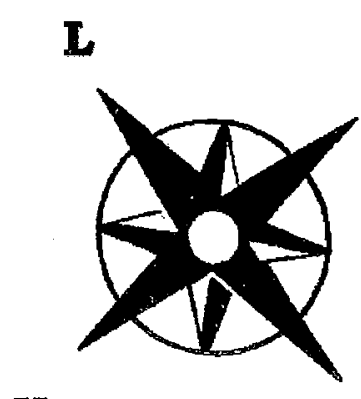

$\mathbf{N}$
$\mathbf{S}$

$\mathbf{0}$

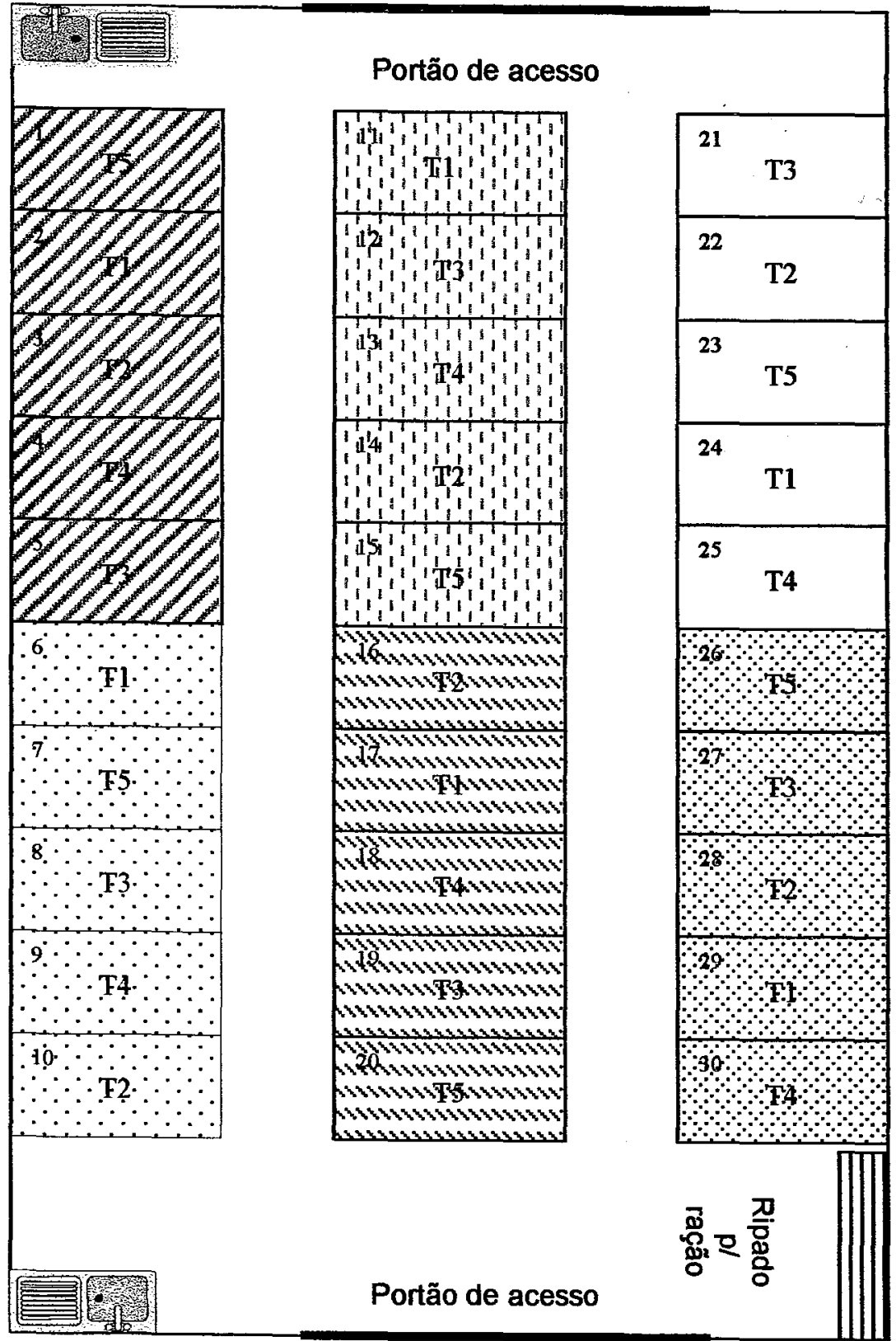

Legenda:

T1-Controle T2-Sulfato T3-Citrato T4-VM T5-Citrato + VM

Bloco 1

Bloco 4 बारापूप

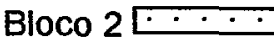

Bloco 5

Bloco 3 प1, 1,

Bloco 6 [थ] 